\title{
Perspectives and potential approaches for targeting neuropilin 1 in SARS-CoV-2 infection
}

Svetlana P. Chapoval 1,2,3,4* and Achsah D. Keegan ${ }^{1,2,3,5}$

\begin{abstract}
Severe acute respiratory syndrome coronavirus 2 (SARS-CoV-2) is a novel type $b$ coronavirus responsible for the COVID-19 pandemic. With over 224 million confirmed infections with this virus and more than 4.6 million people dead because of it, it is critically important to define the immunological processes occurring in the human response to this virus and pathogenetic mechanisms of its deadly manifestation. This perspective focuses on the contribution of the recently discovered interaction of SARS-CoV-2 Spike protein with neuropilin 1 (NRP1) receptor, NRP1 as a virus entry receptor for SARS-CoV-2, its role in different physiologic and pathologic conditions, and the potential to target the Spike-NRP1 interaction to combat virus infectivity and severe disease manifestations.
\end{abstract}

Keywords: ACE2, angiotensin converting enzyme 2, NRP-1, neuropilin-1, Molecular structures, SARS-CoV-2, severe acute respiratory syndrome coronavirus 2, Spike protein, COVID-19, coronavirus disease 2019, Host immune response, Immunotargets and strategies, Comorbidities, CendR C-end rule, RBD, receptor-biding domain

\section{Background}

SARS-CoV-2 infected over 224 million people worldwide leading to more than 4.6 million deaths. Currently, there is no FDA-approved treatment for the SASR-CoV-2 viral disease. Therefore, there is an urgent need for anti-viral therapeutics to treat this and future SARS infections. It is now well-established that SARS-CoV-2 entry into cells is initiated by its Spike protein priming by the transmembrane protease serine 2 (TMPRSS2) and binding to its main receptor in human tissues, the angiotensin-converting enzyme 2 (ACE-2) (Hoffmann et al. 2020b; Wang et al. 2020b; Yan et al. 2020). However, recent data suggest that there are additional mediators of viral entry and cell infectivity (Cantuti-Castelvetri et al. 2020; Daly et al. 2020; Radzikowska et al. 2020; Root-Bernstein 2021).

\footnotetext{
*Correspondence: schapoval@som.umaryland.edu

${ }^{2}$ Center for Vascular and Inflammatory Diseases, University of Maryland School of Medicine, 800 West Baltimore Street, Baltimore, MD 21201, USA Full list of author information is available at the end of the article
}

One such mediator is neuropilin 1 (NRP1) as reported in several recent preclinical and clinical studies (CantutiCastelvetri et al. 2020; Daly et al. 2020; Davies et al. 2020; McFarland et al. 2021; Moutal et al. 2021). In this review, we explored the details of NRP1 expression and function in health and diseases and perspectives of its targeting in order to prevent or abrogate a severe SARS-CoV-2 infection.

\section{SARS-CoV-2 structure}

Several recent publications provide detailed descriptions of SARS-CoV-2 structure and its unique features distinguishing it from SARS-CoV or MERS-CoV (Chen et al. 2020; Chuckran et al. 2020; Hoffmann et al. 2020a, b; Finkelstein et al. 2021; Kadam et al. 2021; Letko et al. 2020; Papageorgiou and Mohsin 2020; Sternberg and Naujokat 2020; Walls et al. 2020; Wang et al. 2020a; Witkowska 2020). SARS-CoV-2 is a single-stranded positive sense RNA virus. Its membrane is composed of several structural proteins such as membrane $(\mathrm{M})$, spike $(\mathrm{S})$, 
and envelope (E) proteins. Viral RNA bound to helical nucleocapsid phosphoproteins $(\mathrm{N})$ is positioned inside the virion. The spike protein of SARS-CoV-2 is an attractive antiviral target and main component (in form of mRNA or DNA) of all FDA- and EU CHFS-approved anti-COVID-19 vaccines (Chen et al. 2020; Letko et al. 2020; Wang et al. 2020a). Spike is a transmembrane homotrimeric glycoprotein of $\sim 180 \mathrm{kDa}$ that belongs to the class I of trimeric fusion proteins and consists of two subunits, S1 and S2 (Wang et al. 2020a). The S protein is cleaved by the transmembrane protease serine 2 (TMPRSS2) which is preferentially expressed on epithelial cells in the airways such as alveolar epithelial type II cells (ATII cells) (reviewed in Sternberg and Naujokat 2020; Hoffmann et al. 2020b). The TMPRSS2-mediated $\mathrm{S}$ protein cleavage and priming are required for its binding to ACE2 receptor, membrane fusion, and cell entry (Sternberg and Naujokat 2020). The S1 subunit of S protein contains a receptor-binding domain (RBD). The S2 subunit contains several domains including a fusion peptide for fusion of virus with a host cell membrane. The S1/S2 boundary includes the cleavage site for the subtilisin-like host cell protease furin which is expressed in all human tissues (Hoffmann et al. 2020a; Sternberg and Naujokat 2020; Walls et al. 2020; Wrapp et al. 2020). The furin cleavage site of $\mathrm{S}$ protein is believed to contribute to the high virulence and tissue tropism of SARS-CoV-2 in humans because of ubiquitous expression of furin and furin-like proteases (Hoffmann et al. 2020a; Walls et al. 2020; Wrapp et al. 2020). Moreover, the envelope proteins of several other viruses such as HIV, influenza, dengue fever, Ebola virus, and Marburg virus utilize furin or furin-like proteases for their cleavage and virus activation (Shiryaev et al. 2007).

\section{ACE2 structure and function}

Angiotensin-converting enzyme 2 (ACE2) is the main cell surface receptor for SARS-CoV-2 (Hoffmann et al. 2020b; Wang et al. 2020b; Yan et al. 2020). ACE2 functions as a physiological counter-balance molecule of ACE. It is a type I integral membrane carboxypeptidase which structure has been solved (Turner 2015; Wan et al. 2020). ACE cleaves vasodilating angiotensin 1 into angiotensin 2 which displays a vasoconstricting function (Hamming et al. 2004; Turner 2015). In contrast, ACE2 causes vasodilation by cleaving and hydrolyzing angiotensin 2 into angiotensin decapeptide 1-7 which signals through the G-protein coupled MasR to induce Akt phosphorylation and NOS production (Bader 2013). Structural biology techniques such as Cryo-Electron Microscopy (Cryo-EM) and X-ray crystallography techniques detail the Spike protein interactions with ACE2 guiding the ongoing therapeutic and vaccination efforts (reviewed in Papageorgiou and Mohsin 2020; Chekol Abebe et al. 2021). Rather low to absent ACE2 expression was detected in all compartments of human respiratory tract. The analysis of three distinct scRNAseq datasets demonstrated low ACE2 expression in ATII cells, bronchial, goblet, and ciliated cells within the airways (Hikmet et al. 2020). Other recent studies reported high ACE2 and transmembrane serine protease 2 (TMPRSS2) expression in nasal epithelium and in lung parenchyma (Sungnak et al. 2020; Yang et al. 2020). Interestingly, analysis of the ACE2 and TMPRSS2 expression pattern in individual cells in the lung and in subsegmental bronchial branches by scRNAseq demonstrated a strong TMPRSS2 expression in both tissues whereas ACE2 was predominantly detected in a transient secretory cell type (Lukassen et al. 2020). The transcriptome analysis also showed that ATII cells co-expressed ACE2 with TMPRSS2. No sex-, age-, or gender-related differences were observed in ACE2 expression in individual cell types in lung cells or in the subsegmental bronchial lung tissue. However, the cell surface receptor expression was not examined in this study. These single cell transcriptome data led to several explanations for the observed relatively high human-tohuman transmission of SARS-CoV-2 when compared to SARS-CoV or MERS-CoV, namely: (a) the binding of SARSCoV-2 to another, yet unknown receptor on the host cell surface, (b) enhanced cleavage of the SARS$\mathrm{CoV}-2 \mathrm{~S}$ protein resulting in higher efficiency of the virus' entry into the cell, and (c) additional host factors increasing the virus entry into the cell by facilitating membrane fusion. All these can explain why SARS-CoV-2 readily infected tissues with relatively low or absent ACE2 expression, such as the respiratory tract and nervous system, pointing to other potentially important factors/ receptors for virus entry (reviewed in Chekol Abebe et al. 2021).

\section{NRP1 structure and function}

Two recent reports in Science demonstrated that the SARS-CoV-2 Spike protein can also bind to the b1b2 domain of NRP1 (Cantuti-Castelvetri et al. 2020; Daly et al. 2020). Unlike SARS-CoV, SARS-CoV-2 contains a polybasic amino acid sequence $\left({ }^{682}{ }^{R R A R}{ }^{685}\right)$ which serves as furin cleavage site which, when cleaved, directly binds NRP1 (Fig. 1) significantly potentiating viral entry and increasing the in vitro cell infectivity with WT virus by $40-70 \%$ depending on the cell type used in the experiments as shown by blocking of NRP1 with Ab or shRNA (Cantuti-Castelvetri et al. 2020; Daly et al. 2020). NRP1 is a single-pass transmembrane glycoprotein, its extracellular portion is involved in semaphorin 3A (Sema3A) and VEGF $_{165}$ binding (Kolodkin et al. 1997; Chapoval et al. 2009; Wild et al. 2012) whereas the c-domain and 


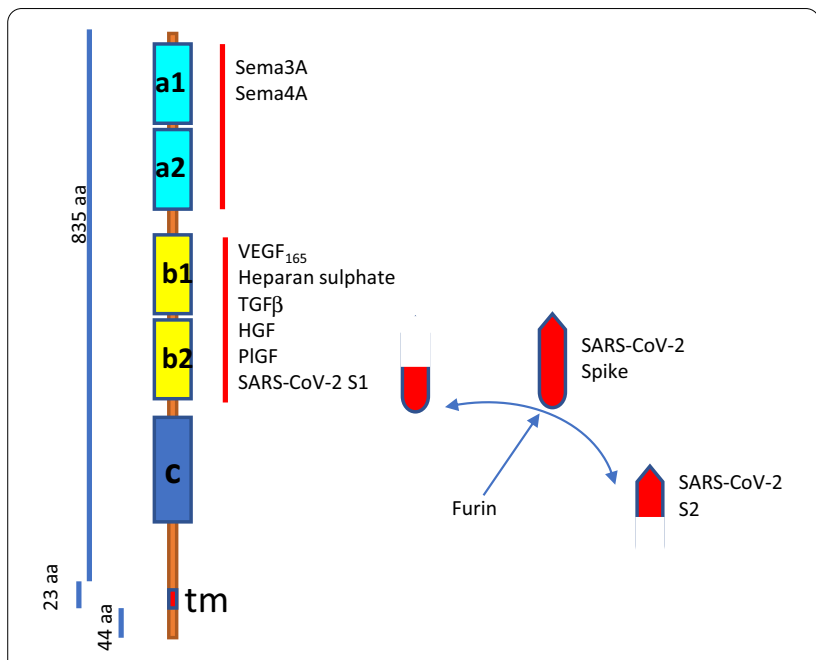

Fig. 1 Neuropilin 1 structure and ligands. NRP1 consists of a large 835 aa extracellular domain, short transmembrane (23 aa) domain, and cytoplasmic (44 aa) portion. Semaphorins $3 \mathrm{~A}$ and $4 \mathrm{~A}$ bind to the a1/a2 domain (also termed CUB domain due to its homology to complement proteins $\mathrm{C} 1 \mathrm{r}$ and $\mathrm{C} 1 \mathrm{~s}$ ), whereas $\mathrm{VEGF}_{165}$, heparan sulphate, TGFb, hepatocytes growth factor (HGF), placental growth factor (PIGF), and SARS-CoV-2 Spike S1 protein bind to the b1/b2 domain (also termed as a coagulation factor homology domain). The $a$ and $b$ domains are critical for binding to the corresponding ligand, whereas the c domain (mephrin or MAM) is important for receptor homodimerization and heterodimerization with Plexin family members. Tm-transmembrane domain. The S1/S2 boundary of the SARS-CoV-2 Spike protein includes the cleavage site for the subtilisin-like host cell protease furin which is expressed in all human tissues. Cleaved S1 through its C-end rule or CendR motif (C-terminal basic sequence motif) directly binds to the b1/b2 domain of NRP1. This binding promotes virus entry and infection

transmembrane portion are involved in receptor dimerization and heteromerization (Wild et al. 2012) (Fig. 1). NRP1 was originally identified in the nervous system. Recent studies have shown its expression in dendritic cells, macrophages (alveolar, bronchial, and intravascular; tumor-associated macrophages), T cell subpopulations $(\mathrm{CD} 8+\mathrm{T}$ cells, Treg cells, Tfh cells, and NKT cells), and mast cells (Bruder et al. 2004; Chekol Abebe et al. 2021; Marone et al. 2016; Roy et al. 2017; Tordjman et al. 2002) demonstrating the important role of NRP1 in the regulation of immune response and in respiratory diseases. NRP1 was also found to be expressed on osteoblasts, renal glomerular mesangial cells, glomerular epithelial cells, neuroendocrine cells of the gastrointestinal tract, adipocytes, kidney's podocytes, olfactory epithelium, and olfactory neurons (reviewed in Chekol Abebe et al. 2021; Roy et al. 2017; Ellis 2006). Mouse NRP1 is a critical receptor for Sema4A acting on Treg cells to regulate their stability and function (Delgoffe et al. 2013). In humans, Plexin B1 plays this Sema4A-dependent potentiating function for Treg cells which lack NRP1 expression (Chapoval et al. 2019). NRP1 is also expressed on $\mathrm{CD} 4{ }^{\text {low }}$ PBMC-derived human monocytes (Chapoval et al. 2019). Therefore, these monocytes might potentially get infected with SARS-CoV-2 virus although the ACE-2 expression on these cells has not been assessed. Interestingly, NRP1 expression was previously detected on lung tissue macrophages by IHC (Aung et al. 2016). These macrophages are believed to be a major source of cytokine overexpression in the "cytokine storm" phenomenon observed in severe SARS-CoV-2 infection (Merad and Martin 2020).

Peptides with a C-terminal basic sequence motif (C-end rule or CendR motif) bind to NRP1 and are taken into cells by endocytosis (Teesalu et al. 2009). The binding of the S1 CendR motif generated by the furin cleavage of Spike protein to NRP1 did not affect cell surface attachment but promoted cell entry and infection by SARS-CoV-2 (Daly et al. 2020). As NRPlis known to mediate the internalization of CendR ligands through an endocytic process resembling micropinocytosis (Teesalu et al. 2009), it is possible that S1 interaction with NRP1 alone, even in the absence of ACE2, may induce a complex internalization presumably by the receptor-mediated CendR endocytosis. This pathway was previously demonstrated in vitro using the NRP1 plasmid-transfected HeLa cells (Pang et al. 2014). However, the intracellular consequences of such internalization for human primary cells have not been explored.

\section{Host immune response to SARS-CoV-2}

Host immune response plays a critical role in protection and fight against SARS-CoV-2. SARS-CoV-2, primarily distributed by air droplets, infects the host's respiratory system. Multiple recent studies have shown that patients infected with SARS-CoV-2 demonstrated pathologic changes in multiple tissues and organs including the gastrointestinal and pancreaticobiliary systems, kidney, heart, and central nervous system (Cheng et al. 2020; Inamdar et al. 2020; Mao et al. 2020; Huang et al. 2021; Karras et al. 2021; Raman et al. 2021; Song et al. 2021a, b). It has been reported that many patients with severe disease have an exaggerated immune response to virus with elevated levels of proinflammatory cytokines IL-1, IL-6, IL-12, and increased IFN $\gamma$, IFN $\gamma$-inducible protein 10, IL-8 (neutrophil chemoattractant), and MCP-1 (monocyte chemoattractant protein 1) (Crestani et al. 1994; Wong et al. 2004a; Zhang et al. 2004). Within the lung tissue, ATII cells could serve as a source of those cytokines and chemokines as they were reported to make IL-6 in vitro and in vivo and participate in intra-alveolar cytokine networks secreting IL-8, IFN, MCP-1, TGF $\beta$, and GM-CSF (Fig. 2) (Crestani et al. 1994; Lin et al. 1998; Yan et al. 2018). Therefore, ATII cells may contribute to a 


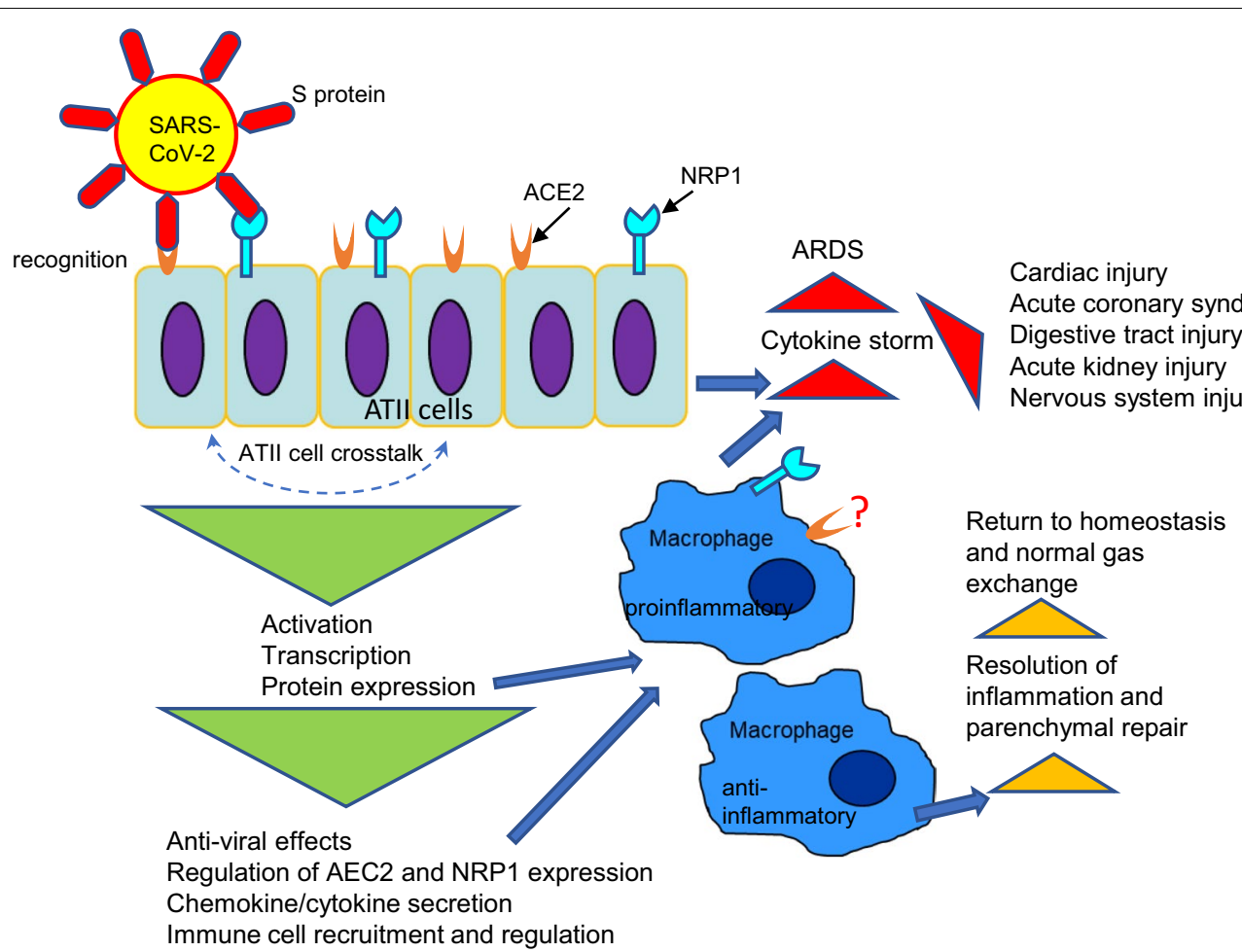

Fig. 2 Integrative model of ATII cell contribution to alveolar macrophage activation and cytokine storm in SARS-CoV-2 infection. ATII cells directly interact with pathogen utilizing ACE2 and NRP1. They induce specific signature signals which activate sentinel cells in the airways to further mount a response. These sentinel cells can reciprocally activate ATII cells by secretion of proinflammatory cytokines. In severe form of disease (red triangles), activation of these cells leads to hyperproduction of cytokines and lung failure. In mild form of infection (orange triangles), anti-inflammatory signature is evoked which eventually leads to macrophage directed initiation of resolution of inflammation and parenchymal repair. Phenotype of alveolar macrophages in SARS depends on a delicate balance between negative and positive regulatory pathways activated by ATII cells. ARDS acute respiratory distress syndrome

local inflammatory response in viral infection by producing chemokines which attract inflammatory cell sequestration into the sites of infection and cytokines which activate those immigrant and local cells (Fig. 2). One recent study in SARS-CoV-2 patients have shown that in addition to the cytokines and chemokines listed above, TNF $\alpha$, IL-2, and IL-7 were significantly elevated in a subset of patients with a fulminant and fatal hypercytokinaemia (Mehta et al. 2020).

\section{Neurologic consequences of SARS-CoV-2 infection and role of NRP1}

SARS-CoV-2 directly and indirectly interacts with the peripheral nervous system and causes pain (McFarland et al. 2021). SARS-CoV-2 induces a complex neurovirulence in humans, a consequence of virus interaction with dorsal root ganglia and trigeminal ganglia. There are distinct neurological effects of SARS-CoV-2 infection on the early and late stages of disease. The human body respond to SARS-CoV-2 by the production and release of type I interferons (McFarland et al. 2021). These cytokines directly interact with corresponding receptor complexes expressed on nociceptors and thus promote pain. This mechanism of SARS-CoV-2 action explains headaches and body aches associated with the disease. However, some patients with severe COVID-19 infection lack type I interferon involvement due to selected SARS-CoV-2 proteins with antagonistic action against IFN-signaling pathways. Another subset of patients which also lack type I IFN involvement because of internal secretion of auto-Abs against type I INFs was particularly susceptible to severe disease (Bastard et al. 2020; McFarland et al. 2021; Lopez et al. 2021; Zhang et al. 2020). Additional cytokine-related mechanism of body aches and pain in SARS-CoV-2 infection is directly linked to ACE2 expression on human skeletal muscles which leads to muscle tissue damage during infection, tissue inflammation, and elevated levels of IL-6 which is known for its nociceptive effects. The inflammatory neuronal demyelination resembling Gullian-Barre syndrome was observed in a subset of patients with severe infection could lead to chronic muscle weakness and fatigue (Finsterer et al. 2021). 
Dorsal root ganglia are reported to express ACE2, furin, and NRP1, the complete receptor machinery for SASR$\mathrm{CoV}-2$ infection. Interestingly, SARS-CoV-2 interaction with NRP1 through its Spike protein binding on nociceptors causes the pain-lowering effects in contrast to its pain-promoting interaction with ACE-2 (Finsterer et al. 2021). This NRP1-linked phenomenon might explain the increased disease transmission in asymptomatic infected individuals (Finsterer et al. 2021; Karuppan et al. 2021). Studies in human brain organoids have clearly demonstrated the SARS-CoV-2 neurotropism but these studies focused on ACE-2 expression and function and omitted the significance of NRP1 (Jacob et al. 2020; Ramani et al. 2021).

Viral infections cause damage to the nervous system with clinical features varying from encephalitis to meningitis with various degrees of severity (Big et al. 2009; Karuppan et al. Karuppan et al., 2021; Singh et al. 2021). SARS-CoV-2 invasion of central nervous systems caused many pathologic effects ranging from reversible brain dysfunction syndrome with headache, dysphoria, mental disorders, and delirium (Mao et al. 2020) to more sever pathologies such as edema of the brain tissue and partial neuronal degeneration (Dixon et al. 2020). The contributions of ACE2 and co-receptor NRP1 to these processes were the subjects of several recent studies (Davies et al. 2020; Karuppan et al. 2021; Khan and Gomes 2020). Whereas ACE-2 expression is rather low in human lung tissue and olfactory epithelium, NRP1 was found to be highly expressed in the lungs and olfactory tubercles and paraolfactory gyri of the human brain (Davies et al. 2020; Karuppan et al. 2021). The detailed examination of a precise NRP1 expression in human brain pointed to a hippocampal formation as the highest NRP1 expressor whereas on the cellular level its expression was detected in endothelial cells, mural cells, neuron clusters, perivascular macrophages and microglia (Davies et al. 2020). The SARS-coV-2 interaction with NRP1 could explain the observed virus entry into olfactory epithelial cells and loss of olfactory function, the ability to detect odorous molecules (sense of smell) in COVID-19 disease. The reduced pain perception in infected asymptomatic patients could be, in part, related to the effect of Spike protein blocking nociceptic VEGF-A/NRP1 interaction (Moutal et al. 2021). SARS-CoV-2 genome was detected in cerebrospinal fluids or infected people and selected patients showed the presence of viral encephalitis (Karuppan et al. 2021). The documented brain dysfunction problems in SARS-CoV-2 infection suggested that the virus can cause infectious toxic or even acute necrotizing encephalopathy. In some patients the virus can lead to the formation of newly detected demyelinating lesions in the brain. All these reports together with known critical function of NRP1 in brain development including the neuronal axon guidance, target recognition, and synaptogenesis (Telley et al. 2016) point to an important role of NRP1 as the Spike protein receptor in the development of serious and prolonged neurological aspects of SARS-CoV-2 infection.

\section{ACE2 and NRP1 targeting strategies to combat SARS-CoV-2 infection}

Several therapeutic strategies for SARS-CoV-2 infection have been proposed, most of them targeting the SARS-CoV-2 Spike-ACE2 interaction (Chan et al. 2020; Kruse 2020; Montail et al. 2020; Wong et al. 2004b). They include: (1) small SARS-CoV-2 Spike protein molecule of 193 aa long containing ACE2-binding domain (RBD) which effectively blocked the virus entry in cell cultures; (2) anti-ACE2 blocking Ab; and (3) soluble ACE2-Fc fusion protein (Lei et al. 2020) to bind and neutralize $S$ protein (Table 1 ). The recently published review by Xiaojie et al. (2020) details the Spike protein targeting drugs based on ACE2 sequences. These drugs include: (1) recombinant soluble ACE2 ectodomain, and (2) its selective mutants which either bind Spike with a higher affinity or express a low catalytic activity which preserve ACE2 function in physiological processes (Table 1). The article by Xiaojie et al. (2020) also summarized the recent development and major structural characteristics of SARS-CoV-2 neutralizing mAbs isolated from convalescent patients, immunized animals, and phage-displayed human antibody libraries. Of note, all these mAbs currently in several clinical studies at different biotech companies were found to target $\mathrm{S} 1$ protein and none of them target S2 protein.

Three NRP1 targeting strategies were used to define its critical role in SARS-CoV-2 infection in vitro, namely: (1) anti-NRP1 neutralizing Ab (Cantuti-Castelvetri et al. 2020; Daly et al. 2020); (2) the small molecule EG00229 acting as a selective NRP1 antagonist (Daly et al. 2020), and (3) soluble extracellular b1b2 domains of NRP1 (Cantuti-Castelvetri et al. 2020) (Table 1). Incubation of Caco-2 cells with anti-NRP1 mAbs raised against the b1b2 ectodomain of NRP1 significantly (by 40\%) reduced SARS-CoV-2 infection as compared to a control mAb targeting avian influenza A virus (H11N3) hemagglutinin (Cantuti-Castelvetri et al. 2020; Daly et al. 2020). Other targeting approach of SARS-CoV-2 entry into cells was based on b1/b2 module of NRP1 as a binding site for VEGF $_{165}$ (Perez-Miller et al. 2020). A library of $5 \times 10^{5}$ compounds was screened for specifically targeting this site; nine chemical series were reported with lead- or drug-like physical and chemical properties, out of which six compounds effectively disrupted VEGFA-NRP-1 interaction, and all nine inhibited VEGF-A 
Table 1 A summary table on SARS-CoV-2 infection targeting strategies

\begin{tabular}{|c|c|c|}
\hline & Research & References \\
\hline \multicolumn{3}{|l|}{ Targeting Spike-ACE2 interaction } \\
\hline $\begin{array}{l}\text { Small SARS-CoV-2 Spike protein molecule of } \\
193 \text { aa long containing ACE2-binding domain } \\
\text { (RBD) }\end{array}$ & Effectively blocked the virus entry in cell cultures & Several studies reviewed in Kruse (2020) \\
\hline Anti-ACE2 blocking Ab & $\begin{array}{l}\text { Immunization of animals and Ab library screen- } \\
\text { ing } \\
\text { Human Ab library screening }\end{array}$ & Reviewed in Kruse (2020), Xiaojie et al. (2020) \\
\hline $\begin{array}{l}\text { Soluble ACE2-Fc fusion protein to bind and } \\
\text { neutralize S protein }\end{array}$ & $\begin{array}{l}\text { Extracellular domain of human ACE2 fused with } \\
\text { the Fc region of the human immunoglobulin } \\
\text { IgG1 shows high-affinity binding to the RBD of } \\
\text { SARS-CoV-2 and potent neuralization of virus } \\
\text { entry in vitro in cell lines }\end{array}$ & Kruse (2020), Lei et al. (2020) \\
\hline Recombinant soluble ACE2 ectodomain & $\begin{array}{l}\text { Effectively competes with native } \\
\text { ACE2 on cell surface to block the subsequent } \\
\text { fusion steps. Inhibit growth of authentic SARS- } \\
\text { CoV-2 in Vero cells and in human organoids }\end{array}$ & Xiaojie et al. (2020), Monteil et al. (2020) \\
\hline Recombinant ACE2 mutants & $\begin{array}{l}\text { Either bind Spike with a higher affinity or express } \\
\text { a low catalytic activity which preserve ACE2 } \\
\text { function in physiological processes }\end{array}$ & $\begin{array}{l}\text { Xiaojie et al. (2020), Monteil et al. (2020), Chan } \\
\text { et al. (2020) }\end{array}$ \\
\hline Anti-Spike Ab from convalescent plasma & $\begin{array}{l}\text { mAbs from a COVID-19 infected subject } 21 \text { days } \\
\text { after the onset of disease identified by using } \\
\text { Spike protein as a bait }\end{array}$ & $\begin{array}{l}\text { Several studies reviewed in Kruse (2020), Lei et al. } \\
\text { (2020) }\end{array}$ \\
\hline Bi-specific fusion protein, ACE-MAB & $\begin{array}{l}\text { One arm is human high affinity anti-Spike Ab. } \\
\text { The other arm is a truncated ACE2 protein that } \\
\text { binds to a different epitope of Spike }\end{array}$ & $\begin{array}{l}\text { Sorrento therapeutics (reviewed in Xiaojie et al. } \\
\text { 2020) }\end{array}$ \\
\hline \multicolumn{3}{|l|}{ Targeting Spike-NRP1 interaction } \\
\hline Anti-NRP1 neutralizing Ab & $\begin{array}{l}\text { Incubation of Caco-2 cells with anti-NRP1 } \\
\text { neutralizing mAbs reduced SARS-CoV-2 infec- } \\
\text { tion compared to a control mAb targeting avian } \\
\text { influenza A virus (H11N3) hemagglutinin }\end{array}$ & Cantuti-Castelvetri et al. (2020), Daly et al. (2020) \\
\hline $\begin{array}{l}\text { Small molecule EG00229 acting as a selective } \\
\text { NRP1 antagonist }\end{array}$ & $\begin{array}{l}\text { Binds the b1 CendR binding pocket and inhibits } \\
\text { VEGF-A binding by NRP1. Incubation of Caco-2 } \\
\text { cells with EG00229 reduced the efficiency of } \\
\text { SARS-CoV- } 2 \text { infection }\end{array}$ & Daly et al. (2020) \\
\hline Soluble b1b2 domain of NRP1 & $\begin{array}{l}\text { When SARS-CoV-2 pseudovirus was preincu- } \\
\text { bated with recombinant, soluble extracellular } \\
\text { b1b2 domain of NRP1, the wild type significantly } \\
\text { reduced cell infection }\end{array}$ & Cantuti-Castelvetri et al. (2020) \\
\hline $\begin{array}{l}\text { Small molecule inhibitors for Spike-NRP1 } \\
\text { interaction }\end{array}$ & $\begin{array}{l}\text { Approach similar to the one recently used to } \\
\text { identify six compounds which effectively dis- } \\
\text { rupted VEGF-A-NRP-1 interaction }\end{array}$ & Perez-Miller et al. (2020) \\
\hline
\end{tabular}

triggered VEGFR2 phosphorylation. These series of lead compounds represent a first step in development of small molecule inhibitors for the SARS-CoV-2 S-NRP1 interaction (Fig. 3) and for certain types of cancer where NRP1 plays a disease-promoting role.

\section{NRP1 in immune response and its targeting in SARS-CoV-2 infection in adults without comorbidities}

The important roles of NRP1 in the immune response have been discussed in several published reviews (Chuckran et al. 2020; Roy et al. 2017; Ellis 2006; Chaudhary et al. 2014; Li et al. 2016). All NRP1-expressing cells may be potential targets for SARS-CoV-2 because Spike protein through its CendR motif that is exposed following furin processing interacts with NRP1 that can leads to a complex internalization through previously described endocytosis (Daly et al. 2020; Teesalu et al. 2009; Jobe and Vijayan 2021). Of note, recent reports clearly showed that without ACE2, NRP1 alone is not able to support efficient virus infection, not even in the immunocompromised HEK 293T cell system (Cantuti-Castelvetri et al. 2020; Daly et al. 2020). Moreover, NRP1 depletion did not affect virus binding to the cell surface but specifically affected the virus uptake (Daly et al. 2020). It is still debated whether SARS-CoV-2 might infect NRP1-expressing DC. However, 


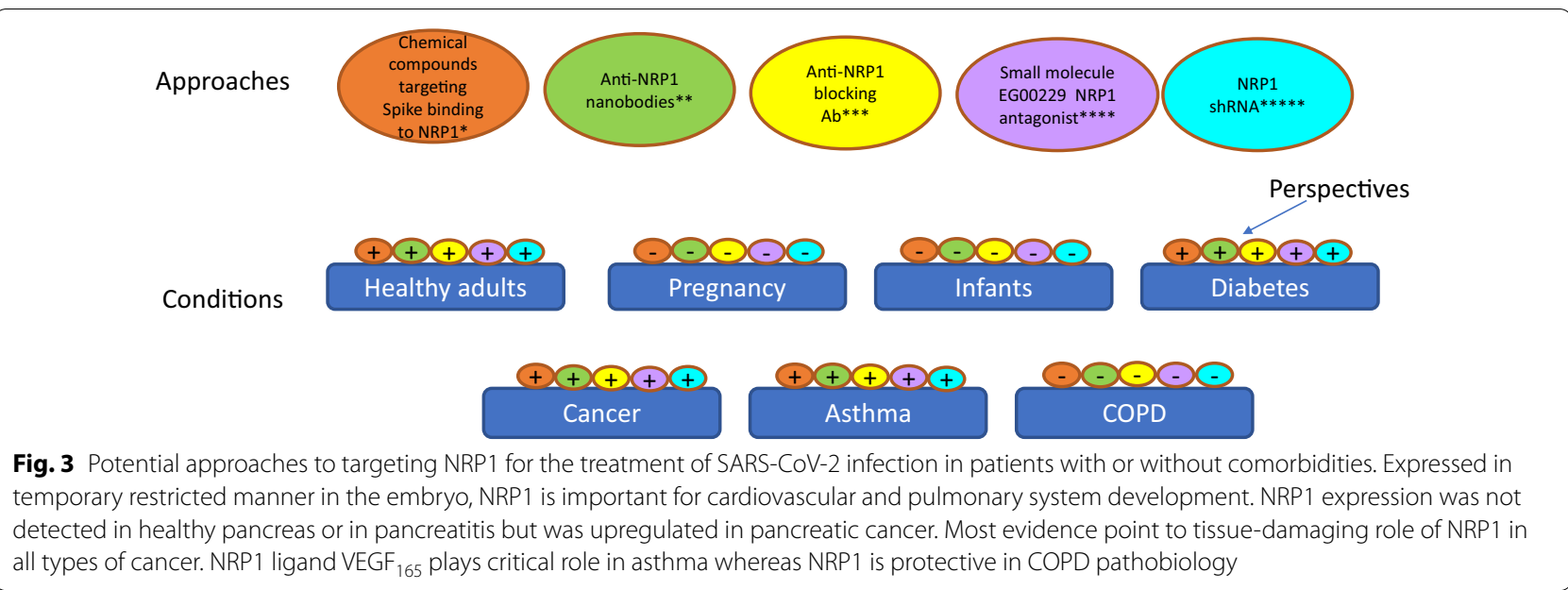

several previous studies have shown that MERS-CoV and SARS-CoV use DC-SIGN as an alternative receptor for DC infection or as a receptor which facilitates virus infectivity through ACE2 (Yang et al. 2004; Marzi et al. 2004; Campana et al. 2020). DC are unmatched in their ability to prime naïve $\mathrm{CD} 4+\mathrm{T}$ cells and initiate and propagate the immune response to given antigen. Among immune cells, NRP1 expression was first identified on human plasmacytoid dendritic cells (pDCs) (Dzionek et al. 2002). Recent findings detect a significant drop in circulating pDC number in SARS-CoV-2 infected patients (Zhou et al. 2020). The mechanisms of such SARS-CoV-2 effect on pDC were not defined. pDCs are known for their type I IFN secretion in response to viral infection. Human pDCs showed potent IFNa release in response to Respiratory Syncytial Virus (RSV) which was inhibited by anti-NRP1 Ab pretreatment of cells (Grage-Griebenow et al. 2007). In addition to its expression on pDCs, NRP1 was also detected on conventional DCs isolated from human peripheral blood, where it potentially promotes $\mathrm{T}$ cell priming by mediating the formation of immunological synapse between cells (Tordjman et al. 2002). NRP1 is expressed on immature DC (iDCs). iDCs do not express costimulatory molecules, are not activated, and can not stimulated $\mathrm{T}$ effector cells. They induce $T$ cell anergy and $T$ cell deletion instead. However, they can stimulate Treg cells to secrete immunosuppressive cytokines such as IL-10 and TGF- $\beta$ (Mahnke et al. 2002). NRP1 was defined as a 'glue' between Tregs and DCs (Mizui and Kikutani 2008; Song et al. 2020). Thus, NRP1 is a critical molecule for immune response to foreign antigen. At the same time, SARS-CoV-2 virus could use NRP1 for DC invasion. It is unclear if DC co-express ACE2 or upregulate ACE2 expression after Spike binding to NRP1. One current study reported little to no expression of ACE2 on immune cells in human peripheral blood including B cells, NK cells, monocytes, dendritic cells, granulocytes, and all subtypes of T cells (Song et al. 2020). However, ACE2 expression was induced or upregulated on $\mathrm{CD} 3+\mathrm{T}$ cells obtained from infected patients while $\mathrm{CD} 20+\mathrm{B}$ cells and the CD16+/HLA-DR+ monocytic/dendritic cells did not change a relatively low ACE2 level as compared to same cell populations obtained from healthy volunteers (Osman et al. 2020).

One published study reported the absence of any significant effect of anti-NRP1 Ab raised to VEGF-binding site of NRP1 on HUVEC cell proliferation and permeability (Pan et al. 2007). This Ab also did not affect VEGF-induced phosphorylation of Erk1/2 or Akt in endothelial cells but significantly inhibited VEGF-induced cell migration. There is one published report on the phase I study of antiNRP1 mAb in patients with advanced solid tumors where this was a well-tolerated approach with promising results (Weekes et al. 2014). Jung et al. (2020) used the NRP1 antagonist [Fc(AAG)-TPP11] generated by fusion of the NRP1-specific binding peptide TPP11 with the C-terminus of an effector function-deficient immunoglobulin Fc(AAG) variant to inhibits intratumoral NRP1+ Treg cell function and stability. The intraperitoneal injections of Fc(AAG)TPP11 into mice with established tumors demonstrated a potent anti-tumoral effect and inhibited tumor growth by $>70 \%$. The NRP1 antagonist effect was comparable to that observed with the use of Treg-depleting anti-CTLA-4 Ab. Other NRP1-directed drugs or biologics have never been examined in vivo.

\section{Perspectives of targeting NRP1 in SARS-CoV-2 infection in pregnant women and infants}

NRP1 is required for normal embryonic vascular, cardiac, and limb development (Kitsukawa et al. 1995; Kawasaki et al. 1999). It was reported to be expressed in a temporary restricted manner in the mouse embryo suggesting that its ectopic or excess expression could cause 
abnormalities (Kitsukawa et al. 1995). Indeed, chimeric embryos with NRP1 overexpression showed abnormal body vascularization and severe pathologies to the cardiovascular and nervous tissues. Such embryos demonstrated lethality at maximum 17.5 pdc (post-conception days of embryonic age) as the result of profound abnormalities to both systems. Therefore, the exogenous NRP1 overexpression causes embryonic death. Such effect was attributed to the unique NRP1 structure which has three domains all potentially involved in different molecular interactions. The observation that different systems are affected by NRP1 overexpression also suggests that NRP1 is a multifunctional molecule. The authors concluded that the correct spatiotemporal patterns of NRP expression were essential for the growth and fasciculation of nerve fibers, formation of the cardiovascular system, and for the limb's formation. Interestingly, a targeting disruption of nrp1 gene was also reported to be embryonic lethal and resulted in multiple defects to the cardiovascular system (Kawasaki et al. 1999). Therefore, NRP1 targeting with Abs or small molecule inhibitors may lead to adverse events in SARS-CoV-2 infection in pregnant women and infants (Fig. 3). However, the drugs based on NRP1 sequence/structure which selectively bind and neutralize SARS-CoV-2 spike protein could be potentially very useful in these groups.

\section{Targeting strategies for NRP1: cancer models}

A number of NRP1-targeting strategies have been developed to treat cancer. The overexpression of NRP1 is reported in several types of cancers such as colon (Parikh et al. 2004), stomach (Mei et al. 2020), lung (Kawakami et al. 2002; Lantuejoul et al. 2003), osteosarcoma (Handa et al. 2000), breast (Stephenson et al. 2002), astrocytoma (Broholm and Laursen 2004), glioma (Hu et al. 2007), melanoma (Graziani and Lacal 2015; Bao et al. 2021), and is considered to be a negative prognostic marker for the disease outcome (reviewed in Ellis 2006; Rizzolio and Tamagnone 2011; Wild et al. 2012). Elevated NRP1 expression was detected in malignant cells and in tumor microenvironment (TME) on macrophages, Treg cells, CD8+ T cells, and dendritic cells (DCs) (reviewed in Chuckran et al. 2020; Moutal et al. 2021; De Vlaemnick et al. 2020; Liu et al. 2020). All these together established a strong association between NRP1 and cancer. Several NRP1-directed therapies such as anti-NRP1 mAb, anti-NRP1 nanobodies, and NRP1 antagonist Fc(AAG)TPP11 demonstrated significant retardation of established tumors without noticeable toxicity (Wild et al. 2012; Weekes et al. 2014; De Vlaeminck et al. 2020; Jung et al. 2020). These studies demonstrate that NRP1 targeting can be highly effective with minimal adverse effects. It could also be considered as an approach in managing and treating the severe SARS-CoV-2 infection in cancer patients (Fig. 3).

\section{Targeting NRP1 in SARS-CoV-2 infection in patients with pulmonary diseases}

Two research groups have described abundant expression of NRP1 in alveolar epithelium (Ito et al. 2000; Roche et al. 2002). However, the functional significance of such expression is unknown. NRP1 expression on epithelial cells may modulate the balance between VEGF and Sema3 signaling in nonepithelial cells (Bagnard et al. 2001; Castro-Rivera et al. 2004). Local lung NRP1 levels gradually increase in the process of lung organogenesis (Roche et al. 2002). NRP1 and its ligands Sema3A and VEGF contribute to the process of alveolar septation aimed to increase blood-gas interchange to supply oxygen to developing organism (Ito et al. 2000; Gerber et al. 1999; Jakkula et al. 2000; McGrath-Morrow et al. 2005; Kunig et al. 2005). Sema3A inhibits branching morphogenesis in lung bud organ cultures acting via NRP1 (Roche et al. 2002), while Sema3C and Sema3F promote lung branching morphogenesis using both NRP1 and NRP2 (Kagoshima and Ito 2001). The NRP1 expression was downregulated in smokers with diagnosed cigarette smoking-induced COPD which displayed defective lung function when compared with smokers with normal lung function and nonsmoking control subjects (Marwick et al. 2006). Therefore, NRP1 plays a protective role in COPD pathobiology and direct targeting of NRP1 in patients with COPD may not be beneficial in case of SARS-CoV-2 infection. Studies in murine models have demonstrated a critical role of NRP1 in proper structural maintenance of lung alveoli (Le et al. 2009). There were more disruptions to alveolar structure in chronic cigarette smoke exposure in mice with conditional epithelial Nrp1 deletion compared to similarly treated WT mice. Interestingly, bronchoalveolar lavage cell composition did not differ significantly between two experimental mouse groups.

The expression of NRP and its ligands in lung cancer is widely reported. Overexpression of both, NRP1 and NRP2 was reported in non-small cell lung carcinoma and it significantly correlated with tumor progression (Kawakami et al. 2002). High levels of NRP1 expression correlated with shorter disease-free and overall survival, and combined overexpression of NRP1 and NRP2 was associated with a worse prognosis than when either NRP was singly overexpressed (Kawakami et al. 2002). A progressive upregulation of NRP levels was observed in different types of lung cancers including squamous cell carcinoma, small cell lung carcinoma, adenocarcinoma, large cell neuroendocrine carcinoma, basaloid carcinoma, and typical and 
atypical carcinoids (Lantuejoul et al. 2003). Expression progresses starting from benign bronchial hyperplasia to dysplasia and then to invasive carcinoma and was correlated with increases in VEGF expression (Lantuejoul et al. 2003). VEGF ${ }_{165}$, one of NRP1 ligands, plays a critical role in allergic asthma (Lee et al. 2004; Bhandari et al. 2006; Chapoval et al. 2009). Expression of both, NRP1 and its another ligand, Sema3A, was found to be upregulated in sputum of asthmatic patients and in BAL and lung homogenates of mice with OVA-induced experimental asthma (Shim et al. 2013) suggesting NRP1 and its ligands play a pathologic role in allergic asthma (Fig. 3). It is possible that targeting of NRP1 to combat SARS-CoV-2 infection in lung cancer and asthma patients will reduce or prevent the severe form of infection.

\section{Targeting NRP1 in SARS-CoV-2 infection in patients with diabetes}

The rate of SARS-CoV-2 infection in people with diabetes is similar to that of general population but postinfection complications are different and much more severe (Apicella et al. 2020; Feldman et al. 2020; Zhou et al. 2021). Moreover, the prevalence of diabetes was $34.6 \%$ in patients with severe COVID-19 (Apicella et al. 2020). One recent report shows that transmembrane protein endothelial and smooth muscle cell-derived neuropilin-like protein (ESDN) serves as an inhibitor of insulin receptor signal transduction in the liver, muscle, and adipose tissue (Li et al. 2016). However, the mechanisms of ESDN action in angiogenesis are distinct from those defined for NRP1 (Nie et al. 2013). A recent study by Wu et al. (2021) found that b-cells in human pancreas express ACE2, TMPRSS2, and selectively high NRP1. SARS-CoV-2 infection in patients affected pancreatic insulin levels, its secretion, and induces b-cell apoptosis. All these events were rescued by NRP1 inhibition. Therefore, b-cells display the necessary molecular machinery for efficient SARS-CoV-2 infection and high NRP1 expression may, in part, explain the SARS-CoV-2 tropism for b-cells. Indeed, a comprehensive analysis of human pancreatic tissue employing the immunofluorescence, immunohistochemistry, RNA scope and electron microscopy demonstrated that $70 \%$ of ACE2 expression was found on pancreas vasculature, whereas b-cell are ACE2+ only in 30\% (Steenblock et al. 2021). The high NRP1 expression on b-cells suggested that the virus uptake could be facilitated by NRP1 when ACE2 expression is low. Therefore, it is tempting to speculate that specific targeting of NRP1 in severe SARS-CoV-2 infection may be a potentially useful strategy in patients with diabetes (Fig. 3).

\section{Other receptors involved in SARS-CoV-2 infection}

Other receptors can facilitate SARS-CoV-2 entry into cells. One such receptor is CD147 or basigin, a transmembrane glycoprotein of the immunoglobulin superfamily which has been shown to increase infectivity of both SARS-CoV and SARS-CoV-2 viruses (Chen et al. 2005; Wang et al. 2020c). The study by Wang et al. (2020c) demonstrated a co-localization of CD147, Spike protein, and Rab5 in BHK-21 cells induced to express CD147 and in lung tissues from patient with SARS-CoV-2 infection. This observation let the authors to conclude that Spike protein binding to CD147 induced a CD147-mediated endocytosis of virus. The results of this study also showed the infection of lung $\mathrm{T}$ cells obtained from COVID19 patients which was mediated by CD147 but not by ACE2 as T cells lack ACE2 expression. The cell infectivity was inhibited by a humanized IgG2 antibody targeting CD147, meplazumab, in a dose-dependent manner. Moreover, the constructed hCD147 transgenic mice, unlike WT littermates, were susceptible to SARS-CoV-2 infection and developed virus-induced pneumonia what further establishes CD147 as an alternative receptor for SARS-CoV-2 entry in an ACE2-deficient environment. However, a recent report by Shilts et al. (2021) showed no evidence for a direct interaction of the SARS-CoV-2 spike protein with basigin. HEK293 cells transfected with basigin full-length cDNA overexpression plasmid were not able to bind a full-length Spike or its S1 domain. Moreover, CRISPR-Cas9-mediated CD147 knockdown in a lung cell line had no effect on cell's susceptibility to SARS-CoV-2 infection whereas knockdown of ACE2 completely blocked viral infection in CaLu-3 cells. Based on these new data, the authors suggested to re-consider all hypotheses relying on Spike protein binding CD147 to explain viral tropism but rather focus on indirect CD147 involvement in SARS-CoV-2-induced disease.

Several recent studies established apilimod, a known pharmacologic blocker of PIKfyve (a $240 \mathrm{kDa}$ class III lipid PI-3P-5-kinase present on the cytosolic face of endosomal membranes) as a potent anti-SARS-CoV-2 agent (Baranov et al. 2020; Kang et al. 2020; Kreutzberger et al. 2021; Riva et al. 2020). Apilimod inhibits the viral capsid fusion with the host cell membrane by inhibiting different lysosomal proteases such as TMPRSS2, furin, trypsin, matriptase, and cathepsin $\mathrm{B} / \mathrm{S} / \mathrm{L}$ (Baranov et al. 2020).

To study a potential interaction between Spike protein and distinct TLRs, the 3D structures of Spike and TLR1, TLR2, TLR4, and TLR5 were retrieved from the RCSB Protein Data Bank and used in the in silico molecular docking studies (Choudhury and Mukherjee 2020). Significant binding of SARS-CoV-2 Spike protein to TLR1, TLR4, and TLR6 was detected with 
a respective binding energy value of $-57.3,-120.2$, and -68.4 . Interestingly, the strongest interaction of Spike protein was with TLR4. This finding was further supported by the in vitro studies where a direct Spike-TLR4 interaction was demonstrated employing TLR4-expressing THP1 cells. Spike protein induced IL-1b production in these cells in a dose-, NF-kB-, and MyD88-dependent manner which was inhibited by the TLR4-specific blocker Resatorvid. MD2 and CD14 were also involved in TLR4 activation by Spike as demonstrated by use of specific blockers such as T5342126 and anti-CD14 $\mathrm{Ab}$, respectively.

Therefore, several immune and non-immune receptors can potentially be utilized by SARS-CoV-2 Spike protein to infect different cells. Such Spike-receptor association may play either a protective or a damaging role in virusinduced disease, an area of research that needs to be further investigated and clarified.

\section{Conclusions}

NRP1 has been shown to participate in the entry of SARS-CoV-2 into cells. Importantly, recent 'omic' analyses revealed a significant upregulation of NRP-1 in biological samples from COVID-19 patients compared to healthy controls (Xiong et al. 2020). Moreover, the increased levels of one NRP1 ligand, VEGF 165 , in bronchial alveolar lavage fluid from COVID-19 patients were also reported (Xiong et al. 2020). VEGF 165 is a physiological ligand for the b1b2 pocket in NRP-1 (Moutal et al. 2021). Spike protein, the major surface antigen of SARSCoV-2, could block VEGF ${ }_{165}$ /NRP-1 signaling. Noteworthy, Sema3A and Sema4A also bind NRP-1 but into a1a2 pocket (Fig. 1). Nevertheless, Sema3A or Sema4A binding may modify the ability of NRP-1 to interact with Spike. The multiple roles of these ligand-receptor interactions in SARS-CoV-2 infection of different cells, tissues, and organs need to be further evaluated. This is an emerging field in research as the roles of NRP1 in different diseases are not well established. Nevertheless, published studies point to NRP1 as potential player in SARS-CoV-2 infection and recently developed approaches for NRP1 targeting provide a foundation for designing novel anti-viral therapies.

\footnotetext{
Abbreviations

ACE2: Angiotensin converting enzyme 2; NRP-1: Neuropilin-1; SARS-CoV-2: Severe acute respiratory syndrome coronavirus 2; COVID-19: Coronavirus disease 2019; VEGF 165 : Vascular endothelial growth factor-A; EU CHFS: European Union Commission for Health and Food Safety; MasR: G-protein coupled Mas receptor; Akt: Protein kinase B; NOS: Nitric oxide species; Sema3A: Semaphorin 3A; Sema4A: Semaphorin 4A; ATII: Alveolar epithelial type II cells; IHC: Immunohistochemistry; CendR: C-end rule; PPC1: Human prostatic cell line; HUVEC: Human umbilical vein endothelial cells; RBD: Receptor-biding domain; RSV: Respiratory syncytial virus; iDC: Immature DC; OVA: Ovalbumin.
}

\section{Acknowledgements}

We thank Dr. Matthew B. Frieman from the Department of Microbiology and Immunology, University of Maryland School of Medicine, for his expert review, comments, and suggestions for this article.

\section{Authors' contributions}

SPC conceptualized the idea, wrote a first draft, and revised the manuscript according to ADK's comments, modifications, and suggestions. Both authors read and approved the final manuscript.

\section{Funding}

S.P.C. is supported by NIH/NIAID RO1 Al076736 and R01 Al143845 grants (both awarded to A.D.K). A.D.K. is also supported by the Merit Review Award Number 101 BX001850 from the US Department of Veterans Affairs Biomedical R\&D Service.

\section{Availability of data and materials}

The dataset supporting the conclusions of this article is included within the article.

\section{Declarations}

Ethics approval and consent to participate

Not applicable for this manuscript.

\section{Consent for publication}

Both authors understand that the text and figures published in the article will be freely available on the internet and may be seen by the general public. The figures and text may also appear on other websites or in print, may be translated into other languages or used for commercial purposes. Both authors contributed to the manuscript. The manuscript is not under consideration elsewhere. The content of the manuscript has not been published. Both authors of the manuscript have read and agreed to its content and are accountable for all aspects of the accuracy and integrity of the manuscript in accordance with ICMJE criteria.

\section{Competing interests}

The authors declare no competing interests.

\section{Author details}

${ }^{1}$ Department of Microbiology and Immunology, University of Maryland School of Medicine, Baltimore, MD, USA. ${ }^{2}$ Center for Vascular and Inflammatory Diseases, University of Maryland School of Medicine, 800 West Baltimore Street, Baltimore, MD 21201, USA. ${ }^{3}$ Program in Oncology at the Greenebaum Cancer Center, University of Maryland School of Medicine, Baltimore, MD, USA. ${ }^{4}$ SemaPlex LLC, Ellicott City, MD, USA. ${ }^{5}$ VA Maryland Health Care System, Baltimore VA Medical Center, Baltimore, MD, USA.

Received: 20 September 2021 Accepted: 13 December 2021 Published online: 27 December 2021

\section{References}

Apicella M, Campopiano MC, Mantuano M, Mazoni L, Coppelli A, Del Prato S. COVID-19 in people with diabetes: understanding the reasons for worse outcomes. Lancet Diabetes Endocrinol. 2020;8(9):782-92. https:// doi.org/10.1016/S2213-8587(20)30238-2.

Aung NY, Ohe R, Meng H, Kabasawa T, Yang S, Kato T, Yamakawa M. Specific neuropilins expression in alveolar macrophages among tissue-specific macrophages. PLoS ONE. 2016;11(2): e0147358. https://doi.org/10. 1371/journal.pone.0147358.

Bader M. ACE2, angiotensin-(1-7), and Mas: the other side of the coin. Pflugers Arch. 2013;465(1):79-85. https://doi.org/10.1007/s00424-012-1120-0.

Bagnard D, Vaillant C, Khuth ST, Dufay N, Lohrum M, Puschel AW, Belin MF, Bolz J, Thomasset N. Semaphorin 3A-vascular endothelial growth factor-165 balance mediates migration and apoptosis of neural progenitor cells by the recruitment of shared receptor. J Neurosci. 2001;21(10):3332-41. https://doi.org/10.1523/JNEUROSCI.21-10-03332.2001. 
Bao R, Surriga O, Olson DJ, Allred JB, Strand CA, Zha Y, Carll T, Labadie BW, Bastos BR, Butler M, Hogg D, Musi E, Ambrosini G, Munster P, Schwartz GK, Luke JJ. Transcriptional analysis of metastatic uveal melanoma survival nominates NRP1 as a therapeutic target. Melanoma Res. 2021;31(1):2737. https://doi.org/10.1097/CMR.0000000000000701.

Baranov MV, Bianchi F, van den Bogaart G. The PIKfyve inhibitor apilimod: a double-edged sword against COVID-19. Cells. 2020;10(1):30. https://doi. org/10.3390/cells10010030.

Bastard P, Rosen LB, Zhang Q, Michailidis E, Hoffmann HH, Zhang Y, Dorgham K, Philippot Q, Rosain J, Béziat V, Manry J, Shaw E, Haljasmägi L, Peterson P, Lorenzo L, Bizien L, Trouillet-Assant S, Dobbs K, de Jesus AA, Belot A, Kallaste A, Catherinot E, Tandjaoui-Lambiotte Y, Le Pen J, Kerner G, Bigio B, Seeleuthner Y, Yang R, Bolze A, Spaan AN, Delmonte OM, Abers MS, Aiuti A, Casari G, Lampasona V, Piemonti L, Ciceri F, Bilguvar K, Lifton RP, Vasse M, Smadja DM, Migaud M, Hadjadj J, Terrier B, Duffy D, QuintanaMurci L, van de Beek D, Roussel L, Vinh DC, Tangye SG, Haerynck F, Dalmau D, Martinez-Picado J, Brodin P, Nussenzweig MC, Boisson-Dupuis S, Rodríguez-Gallego C, Vogt G, Mogensen TH, Oler AJ, Gu J, Burbelo PD, Cohen Jl, Biondi A, Bettini LR, D'Angio M, Bonfanti P, Rossignol P, Mayaux J, Rieux-Laucat F, Husebye ES, Fusco F, Ursini MV, Imberti L, Sottini A, Paghera S, Quiros-Roldan E, Rossi C, Castagnoli R, Montagna D, Licari A, Marseglia GL, Duval X, Ghosn J, Tsang JS, Goldbach-Mansky R, Kisand K, Lionakis MS, Puel A, Zhang SY, Holland SM, Gorochov G, Jouanguy E, Rice CM, Cobat A, Notarangelo LD, Abel L, Su HC, Casanova JL, HGID Lab, NIAID-USUHS Immune Response to COVID Group, COVID Clinicians, COVID-STORM Clinicians, Imagine COVID Group, French COVID Cohort Study Group, Milieu Intérieur Consortium, CoV-Contact Cohort, Amsterdam UMC Covid-19 Biobank, COVID Human Genetic Effort. Autoantibodies against type I IFNs in patients with life-threatening COVID-19. Science. 2020;370(6515): eabd4585. https://doi.org/10.1126/ science.abd4585.

Bhandari V, Choo-Wing R, Chapoval SP, Lee CG, Tang C, Kim YK, Ma B, Baluk P, Lin MI, McDonald DM, Homer RJ, Sessa WC, Elias JA. Essential role of nitric oxide in VEGF-induced, asthma-like angiogenic, inflammatory, mucus, and physiologic responses in the lung. Proc Natl Acad Sci USA 2006;103(29):1 1021-6. https://doi.org/10.1073/pnas.0601057103.

Big C, Reineck LA, Aronoff DM. Viral infections of the central nervous system: a case-based review. Clin Med Res. 2009;7(4):142-6. https://doi.org/10. 3121/cmr.2009.864.

Broholm H, Laursen H. Vascular endothelial growth factor (VEGF) receptor neuropilin-1's distribution in astrocytic tumors. APMIS. 2004;112(45):257-63. https://doi.org/10.1111/j.1600-0463.2004.apm11204-0505.x.

Bruder D, Probst-Kepper M, Westendorf AM, Geffers R, Beissert S, Loser K, von Boehmer H, Buer J, Hansen W. Neuropilin-1: a surface marker of regulatory T cells. Eur J Immunol. 2004;34(3):623-30. https://doi.org/10.1002/ eji.200324799.

Campana P, Parisi V, Leosco D, Bencivenga D, Della Ragione F, Borriello A. Dendritic cells and SARS-CoV-2 infection: still an unclarified connection. Cells. 2020;9(9):2046. https://doi.org/10.3390/cells9092046.

Cantuti-Castelvetri L, Ojha R, Pedro LD, Djannatian M, Franz J, Kuivanen S, van der Meer F, Kallio K, Kaya T, Anastasina M, Smura T, Levanov L, Szirovicza L, Tobi A, Kallio-Kokko H, Österlund P, Joensuu M, Meunier FA, Butcher SJ, Winkler MS, Mollenhauer B, Helenius A, Gokce O, Teesalu T, Hepojoki J, Vapalahti O, Stadelmann C, Balistreri G, Simons M. Neuropilin-1 facilitates SARS-CoV-2 cell entry and infectivity. Science. 2020;370(6518):856-60. https://doi.org/10.1126/science.abd2985.

Castro-Rivera E, Ran S, Thorpe P, Minna JD. Semaphorin 3B (SEMA3B) induces apoptosis in lung and breast cancer, whereas VEGF165 antagonizes this effect. Proc Natl Acad Sci USA. 2004;101(31):11432-7. https://doi.org/ 10.1073/pnas.0403969101.

Chan KK, Dorosky D, Sharma P, Abbasi SA, Dye JM, Kranz DM, Herbert AS, Procko E. Engineering human ACE2 to optimize binding to the spike protein of SARS coronavirus 2. Science. 2020;369(6508):1261-5. https:// doi.org/10.1126/science.abc0870.

Chapoval SP, Lee CG, Tang C, Keegan AD, Cohn L, Bottomly K, Elias JA. Lung vascular endothelial growth factor expression induces local myeloid dendritic cell activation. Clin Immunol. 2009;132(3):371-84. https://doi. org/10.1016/j.clim.2009.05.016.

Chapoval SP, Hritzo M, Qi X, Tamagnone L, Golding A, Keegan AD. Semaphorin $4 \mathrm{~A}$ stabilizes human regulatory $T$ cell phenotype via plexin B1.
Immunohorizons. 2019;3(2):71-87. https://doi.org/10.4049/immun ohorizons. 1800026.

Chaudhary B, Khaled YS, Ammori BJ, Elkord E. Neuropilin 1: function and therapeutic potential in cancer. Cancer Immunol Immunother. 2014;63(2):81-99. https://doi.org/10.1007/s00262-013-1500-0.

Chekol Abebe E, Mengie Ayele T, Tilahun Muche Z, Asmamaw DT. Neuropilin 1: a novel entry factor for SARS-CoV-2 infection and a potential therapeutic target. Biologics. 2021;15:143-52. https://doi.org/10.2147/ BTT.S307352.

Chen Z, Mi L, Xu J, Yu J, Wang X, Jiang J, Xing J, Shang P, Qian A, Li Y, Shaw PX, Wang J, Duan S, Ding J, Fan C, Zhang Y, Yang Y, Yu X, Feng Q, Li B, Yao X, Zhang Z, Li L, Xue X, Zhu P. Function of HAb18G/CD147 in invasion of host cells by severe acute respiratory syndrome coronavirus. J Infect Dis. 2005;191(5):755-60. https://doi.org/10.1086/427811.

Chen WH, Strych U, Hotez PJ, Bottazzi ME. The SARS-CoV-2 vaccine pipeline: an overview. Curr Trop Med Rep. 2020. https://doi.org/10.1007/ s40475-020-00201-6.

Cheng Y, Luo R, Wang X, Wang K, Zhang N, Zhang M, Wang Z, Dong L, Li J, Zeng R, Yao Y, Ge S, Xu G. The incidence, risk factors, and prognosis of acute kidney injury in adult patients with coronavirus disease 2019. Clin J Am Soc Nephrol. 2020;15(10):1394-402. https://doi.org/10.2215/CJN. 04650420.

Choudhury A, Mukherjee S. In silico studies on the comparative characterization of the interactions of SARS-CoV-2 spike glycoprotein with ACE-2 receptor homologs and human TLRs. J Med Virol. 2020;92(10):2105-13. https://doi.org/10.1002/jmv.25987.

Chuckran CA, Liu C, Bruno TC, Workman CJ, Vignali DA. Neuropilin-1: a checkpoint target with unique implications for cancer immunology and immunotherapy. J Immunother Cancer. 2020;8(2): e000967. https://doi. org/10.1136/jitc-2020-000967.

Crestani B, Cornillet P, Dehoux M, Rolland C, Guenounou M, Aubier M. Alveolar type II epithelial cells produce interleukin-6 in vitro and in vivo. Regulation by alveolar macrophage secretory products. J Clin Invest. 1994;94(2):731-40. https://doi.org/10.1172/JCl117392.

Daly JL, Simonetti B, Klein K, Chen KE, Williamson MK, Antón-Plágaro C, Shoemark DK, Simón-Gracia L, Bauer M, Hollandi R, Greber UF, Horvath P, Sessions RB, Helenius A, Hiscox JA, Teesalu T, Matthews DA, Davidson AD, Collins BM, Cullen PJ, Yamauchi Y. Neuropilin-1 is a host factor for SARS-CoV-2 infection. Science. 2020;370(6518):861-5.

Davies J, Randeva HS, Chatha K, Hall M, Spandidos DA, Karteris E, Kyrou I. Neuropilin-1 as a new potential SARS-CoV-2 infection mediator implicated in the neurologic features and central nervous system involvement of COVID-19. Mol Med Rep. 2020;22(5):4221-6. https://doi.org/10.3892/ mmr.2020.11510.

De Vlaeminck Y, Bonelli S, Awad RM, Dewilde M, Rizzolio S, Lecocq Q, Bolli E, Santos AR, Laoui D, Schoonooghe S, Tamagnone L, Goyvaerts C, Mazzone M, Breckpot K, Van Ginderachter JA. Targeting neuropilin-1 with nanobodies reduces colorectal carcinoma development. Cancers. 2020;12(12):3582. https://doi.org/10.3390/cancers12123582.

Delgoffe GM, Woo SR, Turnis ME, Gravano DM, Guy C, Overacre AE, Bettini ML, Vogel P, Finkelstein D, Bonnevier J, Workman CJ, Vignali DA. Stability and function of regulatory $T$ cells is maintained by a neuropilin-1-semaphorin-4a axis. Nature. 2013;501(7466):252-6. https://doi.org/10.1038/ nature12428.

Dixon L, Varley J, Gontsarova A, Mallon D, Tona F, Muir D, Luqmani A, Jenkins $I H$, Nicholas R, Jones B, Everitt A. COVID-19-related acute necrotizing encephalopathy with brain stem involvement in a patient with aplastic anemia. Neurol Neuroimmunol Neuroinflamm. 2020;7(5): e789. https:// doi.org/10.1212/NXI.0000000000000789.

Dzionek A, Inagaki Y, Okawa K, Nagafune J, Röck J, Sohma Y, Winkels G, Zysk M, Yamaguchi Y, Schmitz J. Plasmacytoid dendritic cells: from specific surface markers to specific cellular functions. Hum Immunol. 2002;63(12):1133-48. https://doi.org/10.1016/s0198-8859(02)00752-8.

Ellis LM. The role of neuropilins in cancer. Mol Cancer Ther. 2006;5(5):1099-107. https://doi.org/10.1158/1535-7163.MCT-05-0538.

Feldman EL, Savelieff MG, Hayek SS, Pennathur S, Kretzler M, Pop-Busui R. COVID-19 and diabetes: a collision and collusion of two diseases. Diabetes. 2020;69(12):2549-65. https://doi.org/10.2337/dbi20-0032.

Finkelstein MT, Mermelstein AG, Parker Miller E, Seth PC, Stancofski ED, Fera D. Structural analysis of neutralizing epitopes of the SARS-CoV-2 spike to 
guide therapy and vaccine design strategies. Viruses. 2021;13(1):134. https://doi.org/10.3390/v13010134.

Finsterer J, Scorza FA, Fiorini AC. SARS-CoV-2-associated Guillain-Barre syndrome in 62 patients. Eur J Neurol. 2021;28(1):e10-2. https://doi.org/10. 1111/ene.14544.

Gerber HP, Hillan KJ, Ryan AM, Kowalski J, Keller GA, Rangell L, Wright BD, Radtke F, Aguet M, Ferrara N. VEGF is required for growth and survival in neonatal mice. Development. 1999;126(6):1149-59.

Grage-Griebenow E, Löseke S, Kauth M, Gehlhar K, Zawatzky R, Bufe A. Anti-BDCA-4 (neuropilin-1) antibody can suppress virus-induced IFNalpha production of plasmacytoid dendritic cells. Immunol Cell Biol. 2007;85(5):383-90. https://doi.org/10.1038/sj.icb.7100048.

Graziani G, Lacal PM. Neuropilin-1 as therapeutic target for malignant melanoma. Front Oncol. 2015;3(5):125. https://doi.org/10.3389/fonc.2015. 00125.

Hamming I, Timens W, Bulthuis ML, Lely AT, Navis G, van Goor H. Tissue distribution of ACE2 protein, the functional receptor for SARS coronavirus. A first step in understanding SARS pathogenesis. J Pathol. 2004;203(2):631-7. https://doi.org/10.1002/path.1570.

Handa A, Tokunaga T, Tsuchida T, Lee YH, Kijima H, Yamazaki H, Ueyama Y, Fukuda H, Nakamura M. Neuropilin-2 expression affects the increased vascularization and is a prognostic factor in osteosarcoma. Int J Oncol. 2000;17(2):291-5. https://doi.org/10.3892/ijo.17.2.291.

Hikmet F, Méar L, Edvinsson Å, Micke P, Uhlén M, Lindskog C. The protein expression profile of ACE2 in human tissues. Mol Syst Biol. 2020a;16(7): e9610. https://doi.org/10.15252/msb.20209610.

Hoffmann M, Kleine-Weber H, PöhImann S. A multibasic cleavage site in the spike protein of SARS-CoV-2 is essential for infection of human lung cells. Mol Cell. 2020a;78(4):779-84.e5. https://doi.org/10.1016/j.molcel. 2020.04.022.

Hoffmann M, Kleine-Weber H, Schroeder S, Krüger N, Herrler T, Erichsen S, Schiergens TS, Herrler G, Wu NH, Nitsche A, Müller MA, Drosten C, Pöhlmann S. SARS-CoV-2 cell entry depends on ACE2 and TMPRSS2 and is blocked by a clinically proven protease inhibitor. Cell. 2020b;181(2):271-80.e8. https://doi.org/10.1016/j.cell.2020.02.052.

Hu B, Guo P, Bar-Joseph I, Imanishi Y, Jarzynka MJ, Bogler O, Mikkelsen T, Hirose T, Nishikawa R, Cheng SY. Neuropilin-1 promotes human glioma progression through potentiating the activity of the HGF/SF autocrine pathway. Oncogene. 2007;26(38):5577-86. https://doi.org/10.1038/sj. onc.1210348.

Huang C, Huang L, Wang Y, Li X, Ren L, Gu X, Kang L, Guo L, Liu M, Zhou X, Luo J, Huang Z, Tu S, Zhao Y, Chen L, Xu D, Li Y, Li C, Peng L, Li Y, Xie W, Cui D, Shang L, Fan G, XU J, Wang G, Wang Y, Zhong J, Wang C, Wang J, Zhang D, Cao B. 6-month consequences of COVID-19 in patients discharged from hospital: a cohort study. Lancet. 2021;397(10270):220-32. https:// doi.org/10.1016/S0140-6736(20)32656-8.

Inamdar S, Benias PC, Liu Y, Sejpal DV, Satapathy SK, Trindade AJ, Northwell COVID-19 Research Consortium. Prevalence, risk factors, and outcomes of hospitalized patients with coronavirus disease 2019 presenting as acute pancreatitis. Gastroenterology. 2020;159(6):2226-8.e2. https://doi. org/10.1053/j.gastro.2020.08.044.

Ito T, Kagoshima M, Sasaki Y, Li C, Udaka N, Kitsukawa T, Fujisawa H, Taniguchi M, Yagi T, Kitamura H, Goshima Y. Repulsive axon quidance molecule Sema3A inhibits branching morphogenesis of fetal mouse lung. Mech Dev. 2000;97(1-2):35-45. https://doi.org/10.1016/s0925-4773(00) 00401-9.

Jacob F, Pather SR, Huang WK, Zhang F, Wong SZH, Zhou H, Cubitt B, Fan W, Chen CZ, Xu M, Pradhan M, Zhang DY, Zheng W, Bang AG, Song H, Carlos de la Torre J, Ming GL. Human pluripotent stem cell-derived neural cells and brain organoids reveal SARS-CoV-2 neurotropism predominates in choroid plexus epithelium. Cell Stem Cell. 2020;27(6):937-50. e9. https://doi.org/10.1016/j.stem.2020.09.016.

Jakkula M, Le Cras TD, Gebb S, Hirth KP, Tuder RM, Voelkel NF, Abman SH. Inhibition of angiogenesis decreases alveolarization in the developing rat lung. Am J Physiol Lung Cell Mol Physiol. 2000;279(3):L600-7. https:// doi.org/10.1152/ajplung.2000.279.3.L600

Jobe A, Vijayan R. Neuropilins: C-end rule peptides and their association with nociception and COVID-19. Comput Struct Biotechnol J. 2021;19:188995. https://doi.org/10.1016/j.csbj.2021.03.025.

Jung K, Kim JA, Kim YJ, Lee HW, Kim CH, Haam S, Kim YS. A neuropilin-1 antagonist exerts antitumor immunity by inhibiting the suppressive function of intratumoral regulatory T cells. Cancer Immunol Res. 2020;8(1):46-56. https://doi.org/10.1158/2326-6066.CIR-19-0143.

Kadam SB, Sukhramani GS, Bishnoi P, Pable AA, Barvkar VT. SARS-CoV-2, the pandemic coronavirus: molecular and structural insights. J Basic Microbiol. 2021;61(3):180-202. https://doi.org/10.1002/jobm.202000537.

Kagoshima M, Ito T. Diverse gene expression and function of semaphorins in developing lung: positive and negative regulatory roles of semaphorins in lung branching morphogenesis. Genes Cells. 2001;6(6):559-71. https://doi.org/10.1046/j.1365-2443.2001.00441.x.

Kang YL, Chou YY, Rothlauf PW, Liu Z, Soh TK, Cureton D, Case JB, Chen RE, Diamond MS, Whelan SPJ, Kirchhausen T. Inhibition of PIKfyve kinase prevents infection by Zaire ebolavirus and SARS-CoV-2. Proc Natl Acad Sci USA. 2020;117(34):20803-13. https://doi.org/10.1073/pnas.20078 37117.

Karras A, Livrozet M, Lazareth H, Benichou N, Hulot JS, Fayol A, Chauvet S, Jannot AS, Penet MA, Diehl JL, Godier A, Sanchez O, Mirault T, Thervet E, Pallet N. Proteinuria and clinical outcomes in hospitalized COVID-19 patients: a retrospective single-center study. Clin J Am Soc Nephrol. 2021. https://doi.org/10.2215/CJN.09130620.

Karuppan MKM, Devadoss D, Nair M, Chand HS, Lakshmana MK. SARSCoV-2 infection in the central and peripheral nervous system-associated morbidities and their potential mechanism. Mol Neurobiol. 2021;58(6):2465-80. https://doi.org/10.1007/s12035-020-02245-1.

Kawakami T, Tokunaga T, Hatanaka H, Kijima H, Yamazaki H, Abe Y, Osamura Y, Inoue H, Ueyama Y, Nakamura M. Neuropilin 1 and neuropilin 2 co-expression is significantly correlated with increased vascularity and poor prognosis in nonsmall cell lung carcinoma. Cancer. 2002;95(10):2196-201. https://doi.org/10.1002/cncr.10936.

Kawasaki T, Kitsukawa T, Bekku Y, Matsuda Y, Sanbo M, Yagi T, Fujisawa H. A requirement for neuropilin-1 in embryonic vessel formation. Development. 1999;126(21):4895-902.

Khan S, Gomes J. Neuropathogenesis of SARS-CoV-2 infection. Elife. 2020;9: e59136. https://doi.org/10.7554/eLife.59136.

Kitsukawa T, Shimono A, Kawakami A, Kondoh H, Fujisawa H. Overexpression of a membrane protein, neuropilin, in chimeric mice causes anomalies in the cardiovascular system, nervous system and limbs. Development. 1995;121(12):4309-18.

Kolodkin AL, Levengood DV, Rowe EG, Tai YT, Giger RJ, Ginty DD. Neuropilin is a semaphorin III receptor. Cell. 1997;90(4):753-62. https://doi.org/10. 1016/s0092-8674(00)80535-8.

Kreutzberger AJB, Sanyal A, Ojha R, Pyle JD, Vapalahti O, Balistreri G, Kirchhausen T. Synergistic block of SARS-CoV-2 infection by combined drug inhibition of the host entry factors PIKfyve kinase and TMPRSS2 protease. J Virol. 2021;95(21): e0097521. https://doi.org/10.1128/JVI. 00975-21.

Kruse RL. Therapeutic strategies in an outbreak scenario to treat the novel coronavirus originating in Wuhan, China. F1000Res. 2020;9:72. https:// doi.org/10.12688/f1000research.22211.2.

Kunig AM, Balasubramaniam V, Markham NE, Morgan D, Montgomery G, Grover TR, Abman SH. Recombinant human VEGF treatment enhances alveolarization after hyperoxic lung injury in neonatal rats. Am J Physiol Lung Cell Mol Physiol. 2005;289(4):L529-35. https://doi.org/10.1152/ ajplung.00336.2004

Lantuéjoul S, Constantin B, Drabkin H, Brambilla C, Roche J, Brambilla E. Expression of VEGF, semaphorin SEMA3F, and their common receptors neuropilins NP1 and NP2 in preinvasive bronchial lesions, lung tumours, and cell lines. J Pathol. 2003;200(3):336-47. https://doi.org/10.1002/ path.1367.

Le A, Zielinski R, He C, Crow MT, Biswal S, Tuder RM, Becker PM. Pulmonary epithelial neuropilin-1 deletion enhances development of cigarette smoke-induced emphysema. Am J Respir Crit Care Med. 2009;180(5):396-406. https://doi.org/10.1164/rccm.200809-1483OC.

Lee CG, Link H, Baluk P, Homer RJ, Chapoval S, Bhandari V, Kang MJ, Cohn L, Kim YK, McDonald DM, Elias JA. Vascular endothelial growth factor (VEGF) induces remodeling and enhances TH2-mediated sensitization and inflammation in the lung. Nat Med. 2004;10(10):1095-103. https:// doi.org/10.1038/nm1105.

Lei C, Qian K, LiT, Zhang S, Fu W, Ding M, Hu S. Neutralization of SARS-CoV-2 spike pseudotyped virus by recombinant ACE2-Ig. Nat Commun. 2020;11(1):2070. https://doi.org/10.1038/s41467-020-16048-4. 
Letko M, Marzi A, Munster V. Functional assessment of cell entry and receptor usage for SARS-CoV-2 and other lineage B betacoronaviruses. Nat Microbiol. 2020;5(4):562-9. https://doi.org/10.1038/s41564-020-0688-y.

Li X, Jung JJ, Nie L, Razavian M, Zhang J, Samuel V, Sadeghi MM. The neuropilin-like protein ESDN regulates insulin signaling and sensitivity. Am J Physiol Heart Circ Physiol. 2016;310(9):H1 184-93. https://doi.org/ 10.1152/ajpheart.00782.2015.

Lin Y, Zhang M, Barnes PF. Chemokine production by a human alveolar epithelial cell line in response to Mycobacterium tuberculosis. Infect Immun. 1998;66(3):1121-6. https://doi.org/10.1128/IAl.66.3.1121-1126.1998.

Liu C, Somasundaram A, Manne S, Gocher AM, Szymczak-Workman AL, Vignali KM, Scott EN, Normolle DP, John Wherry E, Lipson EJ, Ferris RL, Bruno TC, Workman CJ, Vignali DAA. Neuropilin-1 is a T cell memory checkpoint limiting long-term antitumor immunity. Nat Immunol. 2020;21 (9):101021. https://doi.org/10.1038/s41590-020-0733-2.

Lopez J, Mommert M, Mouton W, Pizzorno A, Brengel-Pesce K, Mezidi M, Villard M, Lina B, Richard JC, Fassier JB, Cheynet V, Padey B, Duliere V, Julien T, Paul S, Bastard P, Belot A, Bal A, Casanova JL, Rosa-Calatrava M, Morfin F, Walzer T, Trouillet-Assant S. Early nasal type I IFN immunity against SARS-CoV-2 is compromised in patients with autoantibodies against type I IFNs. J Exp Med. 2021;218(10): e20211211. https://doi.org/10. 1084/jem.20211211.

Lukassen S, Chua RL, Trefzer T, Kahn NC, Schneider MA, Muley T, Winter H, Meister M, Veith C, Boots AW, Hennig BP, Kreuter M, Conrad C, Eils R. SARS-CoV-2 receptor ACE2 and TMPRSS2 are primarily expressed in bronchial transient secretory cells. EMBO J. 2020;39(10): e105114. https://doi.org/10.15252/embj.20105114.

Mahnke K, Schmitt E, Bonifaz L, Enk AH, Jonuleit H. Immature, but not inactive: the tolerogenic function of immature dendritic cells. Immunol Cell Biol. 2002;80(5):477-83. https://doi.org/10.1046/j.1440-1711.2002.01115.x.

Mao L, Jin H, Wang M, Hu Y, Chen S, He Q, Chang J, Hong C, Zhou Y, Wang D, Miao X, LiY, Hu B. Neurologic manifestations of hospitalized patients with coronavirus disease 2019 in Wuhan, China. JAMA Neurol. 2020;77(6):683-90. https://doi.org/10.1001/jamaneurol.2020.1127.

Marone G, Varricchi G, Loffredo S, Granata F. Mast cells and basophils in inflammatory and tumor angiogenesis and lymphangiogenesis. Eur J Pharmacol. 2016;778:146-51. https://doi.org/10.1016/j.ejphar.2015.03.088.

Marwick JA, Stevenson CS, Giddings J, MacNee W, Butler K, Rahman I, Kirkham PA. Cigarette smoke disrupts VEGF165-VEGFR-2 receptor signaling complex in rat lungs and patients with COPD: morphological impact of VEGFR-2 inhibition. Am J Physiol Lung Cell Mol Physiol. 2006:290(5):L897-908. https://doi.org/10.1152/ajplung.00116.2005.

Marzi A, Gramberg T, Simmons G, Möller P, Rennekamp AJ, Krumbiegel M, Geier M, Eisemann J, Turza N, Saunier B, Steinkasserer A, Becker S, Bates P, Hofmann H, Pöhlmann S. DC-SIGN and DC-SIGNR interact with the glycoprotein of Marburg virus and the $S$ protein of severe acute respiratory syndrome coronavirus. J Virol. 2004;78(21):12090-5. https://doi.org/ 10.1128/JVI.78.21.12090-12095.2004.

MCFarland AJ, Yousuf MS, Shiers S, Price TJ. Neurobiology of SARS-CoV-2 interactions with the peripheral nervous system: implications for COVID-19 and pain. Pain Rep. 2021;6(1): e885. https://doi.org/10.1097/PR9.00000 00000000885

McGrath-Morrow SA, Cho C, Cho C, Zhen L, Hicklin DJ, Tuder RM. Vascular endothelial growth factor receptor 2 blockade disrupts postnatal lung development. Am J Respir Cell Mol Biol. 2005;32(5):420-7. https://doi. org/10.1165/rcmb.2004-02870C.

Mehta P, McAuley DF, Brown M, Sanchez E, Tattersall RS, Manson JJ, HLH Across Speciality Collaboration, UK. COVID-19: consider cytokine storm syndromes and immunosuppression. Lancet. 2020;395(10229):1033-4. https://doi.org/10.1016/S0140-6736(20)30628-0.

Mei B, Chen J, Yang N, Peng Y. The regulatory mechanism and biological significance of the Snail-miR590-VEGFR-NRP1 axis in the angiogenesis, growth and metastasis of gastric cancer. Cell Death Dis. 2020;11(4):241. https://doi.org/10.1038/s41419-020-2428-x.

Merad M, Martin JC. Pathological inflammation in patients with COVID19: a key role for monocytes and macrophages. Nat Rev Immunol. 2020;20(6):355-62. https://doi.org/10.1038/s41577-020-0331-4.

Mizui M, Kikutani H. Neuropilin-1: the glue between regulatory $T$ cells and dendritic cells? Immunity. 2008;28(3):302-3. https://doi.org/10.1016/j. immuni.2008.02.012.
Monteil V, Kwon H, Prado P, Hagelkrüys A, Wimmer RA, Stahl M, Leopoldi A, Garreta E, Hurtado Del Pozo C, Prosper F, Romero JP, Wirnsberger G, Zhang H, Slutsky AS, Conder R, Montserrat N, Mirazimi A, Penninger JM. Inhibition of SARS-CoV-2 infections in engineered human tissues using clinical-grade soluble human ACE2. Cell. 2020;181(4):905-13.e7. https:// doi.org/10.1016/j.cell.2020.04.004.

Moutal A, Martin LF, Boinon L, Gomez K, Ran D, Zhou Y, Stratton HJ, Cai S, Luo S, Gonzalez KB, Perez-Miller S, Patwardhan A, Ibrahim MM, Khanna R. SARS-CoV-2 spike protein co-opts VEGF-A/neuropilin-1 receptor signaling to induce analgesia. Pain. 2021;162(1):243-52. https://doi.org/10. 1097/j.pain.0000000000002097.

Nie L, Guo X, Esmailzadeh L, Zhang J, Asadi A, Collinge M, Li X, Kim JD, Woolls M, Jin SW, Dubrac A, Eichmann A, Simons M, Bender JR, Sadeghi MM. Transmembrane protein ESDN promotes endothelial VEGF signaling and regulates angiogenesis. J Clin Invest. 2013;123(12):5082-97. https:// doi.org/10.1172/JCl67752.

Osman Ol, Melenotte C, Brouqui P, Million M, Lagier J-C, Parola P, Stein A, La Scola B, Meddeb L, Mege J-L, Raoult D, Davaux CA. Expression of ACE2 receptor, soluble ACE2, angiotensin I, angiotensin II 5 and angiotensin (1-7), is modulated in COVID-19 patients. medRxiv. 2020. https://doi. org/10.1101/2021.02.08.21251001.

Pan Q, Chanthery Y, Liang WC, Stawicki S, Mak J, Rathore N, Tong RK, Kowalski J, Yee SF, Pacheco G, Ross S, Cheng Z, Le Couter J, Plowman G, Peale F, Koch AW, Wu Y, Bagri A, Tessier-Lavigne M, Watts RJ. Blocking neuropilin-1 function has an additive effect with anti-VEGF to inhibit tumor growth. Cancer Cell. 2007;11(1):53-67. https://doi.org/10.1016/j.ccr. 2006.10.018.

Pang HB, Braun GB, Friman T, Aza-Blanc P, Ruidiaz ME, Sugahara KN, Teesalu T, Ruoslahti E. An endocytosis pathway initiated through neuropilin-1 and regulated by nutrient availability. Nat Commun. 2014;5:4904. https:// doi.org/10.1038/ncomms5904.

Papageorgiou AC, Mohsin I. The SARS-CoV-2 spike glycoprotein as a drug and vaccine target: structural insights into its complexes with ACE2 and antibodies. Cells. 2020;9(11):2343. https://doi.org/10.3390/cells9112343.

Parikh AA, Fan F, Liu WB, Ahmad SA, Stoeltzing O, Reinmuth N, Bielenberg D, Bucana CD, Klagsbrun M, Ellis LM. Neuropilin-1 in human colon cancer: expression, regulation, and role in induction of angiogenesis. Am J Pathol. 2004;164(6):2139-51. https://doi.org/10.1016/S0002-9440(10) 63772-8.

Perez-Miller S, Patek M, Moutal A, Cabel CR, Thorne CA, Campos SK, Khanna $R$. In silico identification and validation of inhibitors of the interaction between neuropilin receptor 1 and SARS-CoV-2 Spike protein. bioRxiv. 2020. https://doi.org/10.1101/2020.09.22.308783.

Radzikowska U, Ding M, Tan G, Zhakparov D, Peng Y, Wawrzyniak P, Wang M, Li S, Morita H, Altunbulakli C, Reiger M, Neumann AU, Lunjani N, Traidl-Hoffmann C, Nadeau KC, O'Mahony L, Akdis C, Sokolowska M. Distribution of ACE2, CD147, CD26, and other SARS-CoV-2 associated molecules in tissues and immune cells in health and in asthma, COPD, obesity, hypertension, and COVID-19 risk factors. Allergy. 2020;75(11):2829-45. https://doi.org/10.1111/all.14429.

Raman B, Cassar MP, Tunnicliffe EM, Filippini N, Griffanti L, Alfaro-Almagro F, Okell T, Sheerin F, Xie C, Mahmod M, Mózes FE, Lewandowski AJ, Ohuma EO, Holdsworth D, Lamlum H, Woodman MJ, Krasopoulos C, Mills R, McConnell FAK, Wang C, Arthofer C, Lange FJ, Andersson J, Jenkinson M, Antoniades C, Channon KM, Shanmuganathan M, Ferreira VM, Piechnik SK, Klenerman P, Brightling C, Talbot NP, Petousi N, Rahman NM, Ho LP, Saunders K, Geddes JR, Harrison PJ, Pattinson K, Rowland MJ, Angus BJ, Gleeson F, Pavlides M, Koychev I, Miller KL, Mackay C, Jezzard P, Smith SM, Neubauer S. Medium-term effects of SARS-CoV-2 infection on multiple vital organs, exercise capacity, cognition, quality of life and mental health, post-hospital discharge. EClinicalMedicine. 2021;31: 100683. https://doi.org/10.1016/j.eclinm.2020.100683.

Ramani A, Pranty Al, Gopalakrishnan J. Neurotropic effects of SARSCoV-2 modeled by the human brain organoids. Stem Cell Rep. 2021;16(3):373-84. https://doi.org/10.1016/j.stemcr.2021.02.007.

Riva L, Yuan S, Yin X, Martin-Sancho L, Matsunaga N, Pache L, BurgstallerMuehlbacher S, De Jesus PD, Teriete P, Hull MV, Chang MW, Chan JF, Cao J, Poon VK, Herbert KM, Cheng K, Nguyen TH, Rubanov A, Pu Y, Nguyen C, Choi A, Rathnasinghe R, Schotsaert M, Miorin L, Dejosez M, Zwaka TP, Sit KY, Martinez-Sobrido L, Liu WC, White KM, Chapman ME, Lendy EK, Glynne RJ, Albrecht R, Ruppin E, Mesecar AD, Johnson JR, Benner C, Sun 
R, Schultz PG, Su Al, García-Sastre A, Chatterjee AK, Yuen KY, Chanda SK. Discovery of SARS-CoV-2 antiviral drugs through large-scale compound repurposing. Nature. 2020;586(7827):113-9. https://doi.org/10.1038/ s41586-020-2577-1.

Rizzolio S, Tamagnone L. Multifaceted role of neuropilins in cancer. Curr Med Chem. 2011;18(23):3563-75. https://doi.org/10.2174/092986711796642 544.

Roche J, Drabkin H, Brambilla E. Neuropilin and its ligands in normal lung and cancer. Adv Exp Med Biol. 2002;515:103-14. https://doi.org/10.1007/ 978-1-4615-0119-0_9.

Root-Bernstein R. Innate receptor activation patterns involving TLR and NLR synergisms in COVID-19, ALI/ARDS and sepsis cytokine storms: a review and model making novel predictions and therapeutic suggestions. Int J Mol Sci. 2021;22(4):2108. https://doi.org/10.3390/ijms22042108.

Roy S, Bag AK, Singh RK, Talmadge JE, Batra SK, Datta K. Multifaceted role of neuropilins in the immune system: potential targets for immunotherapy. Front Immunol. 2017;8:1228. https://doi.org/10.3389/fimmu. 2017.01228.

Shilts J, Crozier TWM, Greenwood EJD, Lehner PJ, Wright GJ. No evidence for basigin/CD147 as a direct SARS-CoV-2 spike binding receptor. Sci Rep. 2021;11(1):413. https://doi.org/10.1038/s41598-020-80464-1.

Shim EJ, Chun E, Kang HR, Cho SH, Min KU, Park HW. Expression of semaphorin 3A and neuropilin 1 in asthma. J Korean Med Sci. 2013;28(10):1435-42. https://doi.org/10.3346/jkms.2013.28.10.1435.

Shiryaev SA, Remacle AG, Ratnikov BI, Nelson NA, Savinov AY, Wei G, Bottini M, Rega MF, Parent A, Desjardins R, Fugere M, Day R, Sabet M, Pellecchia M, Liddington RC, Smith JW, Mustelin T, Guiney DG, Lebl M, Strongin AY. Targeting host cell furin proprotein convertases as a therapeutic strategy against bacterial toxins and viral pathogens. J Biol Chem. 2007;282(29):20847-53. https://doi.org/10.1074/jbc.M703847200.

Singh H, Koury J, Kaul M. Innate immune sensing of viruses and its consequences for the central nervous system. Viruses. 2021;13(2):170. https:// doi.org/10.3390/v13020170.

Song X, Hu W, Yu H, Zhao L, Zhao Y, Zhao X, Xue HH, Zhao Y. Little to no expression of angiotensin-converting enzyme-2 on most human peripheral blood immune cells but highly expressed on tissue macrophages. Cytometry A. 2020. https://doi.org/10.1002/cyto.a.24285.

Song E, Zhang C, Israelow B, Lu-Culligan A, Prado AV, Skriabine S, Lu P, Weizman OE, Liu F, Dai Y, Szigeti-Buck K, Yasumoto Y, Wang G, Castaldi C, Heltke J, Ng E, Wheeler J, Alfajaro MM, Levavasseur E, Fontes B, Ravindra NG, Van Dijk D, Mane S, Gunel M, Ring A, Kazmi SAJ, Zhang K, Wilen CB, Horvath TL, Plu I, Haik S, Thomas JL, Louvi A, Farhadian SF, Huttner A, Seilhean D, Renier N, Bilguvar K, Iwasaki A. Neuroinvasion of SARSCoV-2 in human and mouse brain. J Exp Med. 2021a;218(3): e20202135. https://doi.org/10.1084/jem.20202135.

Song Z, Bao L, Yu P, Qi F, Gong S, Wang J, Zhao B, Liu M, Han Y, Deng W, Liu J, Wei Q, Xue J, Zhao W, Qin C. SARS-CoV-2 causes a systemically multiple organs damages and dissemination in hamsters. Front Microbiol. 2021b;12(11): 618891. https://doi.org/10.3389/fmicb.2020.618891.

Steenblock C, Richter S, Berger I, Barovic M, Schmid J, Schubert U, Jarzebska $\mathrm{N}$, von Mässenhausen A, Linkermann A, Schürmann A, Pablik J, Dienemann T, Evert K, Rodionov RN, Semenova NY, Zinserling VA, Gainetdinov RR, Baretton G, Lindemann D, Solimena M, Ludwig B, Bornstein SR. Viral infiltration of pancreatic islets in patients with COVID-19. Nat Commun. 2021;12(1):3534. https://doi.org/10.1038/s41467-021-23886-3.

Stephenson JM, Banerjee S, Saxena NK, Cherian R, Banerjee SK. Neuropilin-1 is differentially expressed in myoepithelial cells and vascular smooth muscle cells in preneoplastic and neoplastic human breast: a possible marker for the progression of breast cancer. Int J Cancer. 2002;101(5):409-14. https://doi.org/10.1002/ijc.10611.

Sternberg A, Naujokat C. Structural features of coronavirus SARS-CoV-2 spike protein: targets for vaccination. Life Sci. 2020;257: 118056. https://doi. org/10.1016/j.lfs.2020.118056.

Sungnak W, Huang N, Bécavin C, Berg M, Queen R, Litvinukova M, TalaveraLópez C, Maatz H, Reichart D, Sampaziotis F, Worlock KB, Yoshida M, Barnes JL, HCA Lung Biological Network. SARS-CoV-2 entry factors are highly expressed in nasal epithelial cells together with innate immune genes. Nat Med. 2020;26(5):681-7.

Teesalu T, Sugahara KN, Kotamraju VR, Ruoslahti E. C-end rule peptides mediate neuropilin-1-dependent cell, vascular, and tissue penetration. Proc
Natl Acad Sci USA. 2009;106(38):16157-62. https://doi.org/10.1073/ pnas.0908201106.

Telley L, Cadilhac C, Cioni JM, Saywell V, Jahannault-Talignani C, Huettl RE, Sarrailh-Faivre C, Dayer A, Huber AB, Ango F. Dual function of NRP1 in axon guidance and subcellular target recognition in cerebellum. Neuron. 2016;91 (6):1276-91. https://doi.org/10.1016/j.neuron.2016.08.015

Tordjman R, Lepelletier Y, Lemarchandel V, Cambot M, Gaulard P. Hermine O, Roméo PH. A neuronal receptor, neuropilin-1, is essential for the initiation of the primary immune response. Nat Immunol. 2002;3(5):477-82. https://doi.org/10.1038/ni789.

Turner AJ. Chapter 25: ACE2 cell biology, regulation, and physiological functions. In: The protective arm of the renin-angiotensin system (RAS). Amsterdam: Elsevier; 2015. p. 185-9. https://doi.org/10.1016/B978-012-801364-9.00025-0.

Walls AC, Park YJ, Tortorici MA, Wall A, McGuire AT, Veesler D. Structure, function, and antigenicity of the SARS-CoV-2 spike glycoprotein. Cell. 2020;181(2):281-92.e6. https://doi.org/10.1016/j.cell.2020.02.058.

Wan Y, Shang J, Graham R, Baric RS, Li F. Receptor recognition by the novel coronavirus from Wuhan: an analysis based on decade-long structural studies of SARS coronavirus. J Virol. 2020;94(7):e00127-20. https://doi. org/10.1128/JVI.00127-20.

Wang MY, Zhao R, Gao LJ, Gao XF, Wang DP, Cao JM. SARS-CoV-2: structure, biology, and structure-based therapeutics development. Front Cell Infect Microbiol. 2020a;25(10): 587269. https://doi.org/10.3389/fcimb. 2020.587269.

Wang Q, Zhang Y, Wu L, Niu S, Song C, Zhang Z, Lu G, Qiao C, Hu Y, Yuen KY, Wang Q, Zhou H, Yan J, Qi J. Structural and functional basis of SARSCoV-2 entry by using human ACE2. Cell. 2020b;181(4):894-904.e9. https://doi.org/10.1016/j.cell.2020.03.045.

Wang K, Chen W, Zhang Z, et al. CD147-spike protein is a novel route for SARSCoV-2 infection to host cells. Sig Transduct Target Ther. 2020c;5:283. https://doi.org/10.1038/s41392-020-00426-x.

Weekes CD, Beeram M, Tolcher AW, Papadopoulos KP, Gore L, Hegde P, Xin Y, Yu R, Shih LM, Xiang H, Brachmann RK, Patnaik A. A phase I study of the human monoclonal anti-NRP1 antibody MNRP1685A in patients with advanced solid tumors. Invest New Drugs. 2014;32(4):653-60. https:// doi.org/10.1007/s10637-014-0071-z.

Wild JR, Staton CA, Chapple K, Corfe BM. Neuropilins: expression and roles in the epithelium. Int J Exp Pathol. 2012;93(2):81-103. https://doi.org/10. 1111/j.1365-2613.2012.00810.x.

Witkowska D. Mass spectrometry and structural biology techniques in the studies on the coronavirus-receptor interaction. Molecules. 2020;25(18):4133. https://doi.org/10.3390/molecules25184133.

Wong CK, Lam CW, Wu AK, Ip WK, Lee NL, Chan IH, Lit LC, Hui DS, Chan MH, Chung SS, Sung JJ. Plasma inflammatory cytokines and chemokines in severe acute respiratory syndrome. Clin Exp Immunol. 2004a;136(1):95103. https://doi.org/10.1111/j.1365-2249.2004.02415.x.

Wong SK, Li W, Moore MJ, Choe H, Farzan M. A 193-amino acid fragment of the SARS coronavirus $S$ protein efficiently binds angiotensin-converting enzyme 2. J Biol Chem. 2004b;279(5):3197-201. https://doi.org/10. 1074/jbc.C300520200.

Wrapp D, Wang N, Corbett KS, Goldsmith JA, Hsieh CL, Abiona O, Graham BS, McLellan JS. Cryo-EM structure of the 2019-nCoV spike in the prefusion conformation. Science. 2020;367(6483):1260-3. https://doi.org/10.1126/ science.abb2507.

Wu CT, Lidsky PV, Xiao Y, Lee IT, Cheng R, Nakayama T, Jiang S, Demeter J, Bevacqua RJ, Chang CA, Whitener RL, Stalder AK, Zhu B, Chen H, Goltsev Y, Tzankov A, Nayak JV, Nolan GP, Matter MS, Andino R, Jackson PK. SARSCoV-2 infects human pancreatic $\beta$ cells and elicits $\beta$ cell impairment. Cell Metab. 2021;33(8):1565-76.e5. https://doi.org/10.1016/j.cmet.2021. 05.013 .

Xiaojie S, Yu L, Lei Y, Guang Y, Min Q. Neutralizing antibodies targeting SARSCoV-2 spike protein. Stem Cell Res. 2020;50: 102125. https://doi.org/10. 1016/.scr.2020.102125.

Xiong Y, Liu Y, Cao L, Wang D, Guo M, Jiang A, Guo D, Hu W, Yang J, Tang Z, Wu H, Lin Y, Zhang M, Zhang Q, Shi M, Liu Y, Zhou Y, Lan K, Chen Y. Transcriptomic characteristics of bronchoalveolar lavage fluid and peripheral blood mononuclear cells in COVID-19 patients. Emerg Microbes Infect. 2020;9(1):761-70. https://doi.org/10.1080/22221751.2020.1747363.

Yan C, Deng C, Liu X, Chen Y, Ye J, Cai R, Shen Y, Tang H. TNF-a induction of IL-6 in alveolar type II epithelial cells: contributions of JNK/C-Jun/AP-1 
element, C/EBPS/C/EBP binding site and IKK/NF-KB p65/KB site. Mol Immunol. 2018;101:585-96. https://doi.org/10.1016/j.molimm.2018.05. 004.

Yan R, Zhang Y, Li Y, Xia L, Guo Y, Zhou Q. Structural basis for the recognition of SARS-CoV-2 by full-length human ACE2. Science. 2020;367(6485):14448. https://doi.org/10.1126/science.abb2762.

Yang ZY, Huang Y, Ganesh L, Leung K, Kong WP, Schwartz O, Subbarao K, Nabel GJ. pH-dependent entry of severe acute respiratory syndrome coronavirus is mediated by the spike glycoprotein and enhanced by dendritic cell transfer through DC-SIGN. J Virol. 2004;78(11):5642-50. https://doi. org/10.1128/JVI.78.11.5642-5650.2004.

Yang C, Li Y, Xiao SY. Differential expression of ACE2 in the respiratory tracts and its relationship to COVID-19 pathogenesis. EBioMedicine. 2020;60: 103004.

Zhang Y, Li J, Zhan Y, Wu L, Yu X, Zhang W, Ye L, Xu S, Sun R, Wang Y, Lou J. Analysis of serum cytokines in patients with severe acute respiratory syndrome. Infect Immun. 2004;72(8):4410-5. https://doi.org/10.1128/ |Al.72.8.4410-4415.2004.

Zhang Q, Bastard P, Liu Z, Le Pen J, Moncada-Velez M, Chen J, Ogishi M, Sabli IKD, Hodeib S, Korol C, Rosain J, Bilguvar K, Ye J, Bolze A, Bigio B, Yang R, Arias AA, Zhou Q, Zhang Y, Onodi F, Korniotis S, Karpf L, Philippot Q, Chbihi M, Bonnet-Madin L, Dorgham K, Smith N, Schneider WM, Razooky BS, Hoffmann HH, Michailidis E, Moens L, Han JE, Lorenzo L, Bizien L, Meade P, Neehus AL, Ugurbil AC, Corneau A, Kerner G, Zhang P, Rapaport F, Seeleuthner Y, Manry J, Masson C, Schmitt Y, Schlüter A, Le Voyer T, Khan T, Li J, Fellay J, Roussel L, Shahrooei M, Alosaimi MF, Mansouri D, Al-Saud H, Al-Mulla F, Almourfi F, Al-Muhsen SZ, Alsohime F, Al Turki S, Hasanato R, van de Beek D, Biondi A, Bettini LR, D'Angio' M, Bonfanti P, Imberti L, Sottini A, Paghera S, Quiros-Roldan E, Rossi C, Oler AJ, Tompkins MF, Alba C, Vandernoot I, Goffard JC, Smits G, Migeotte I, Haerynck F, Soler-Palacin P, Martin-Nalda A, Colobran R, Morange PE, Keles S, Çölkesen F, OzcelikT, Yasar KK, Senoglu S, Karabela ŞN, Rodríguez-Gallego C, Novelli G, Hraiech S, Tandjaoui-Lambiotte Y, Duval X, Laouénan C, Snow AL, Dalgard CL, Milner JD, Vinh DC, Mogensen TH, Marr N, Spaan AN, Boisson B, Boisson-Dupuis S, Bustamante J, Puel A, Ciancanelli MJ, Meyts I, Maniatis T, Soumelis V, Amara A, Nussenzweig M, García-Sastre A, Krammer F, Pujol A, Duffy D, Lifton RP, Zhang SY, Gorochov G, Béziat V, Jouanguy E, Sancho-Shimizu V, Rice CM, Abel L, Notarangelo LD, Cobat A, Su HC, Casanova JL, COVID-STORM Clinicians, COVID Clinicians, Imagine COVID Group, French COVID Cohort Study Group, CoV-Contact Cohort, Amsterdam UMC Covid-19 Biobank, COVID Human Genetic Effort, NIAID-USUHS/TAGC COVID Immunity Group. Inborn errors of type I IFN immunity in patients with life-threatening COVID-19. Science. 2020;370(6515): eabd4570. https://doi.org/10.1126/ science.abd4570.

Zhou R, To KK, Wong YC, Liu L, Zhou B, Li X, Huang H, Mo Y, Luk TY, Lau TT, Yeung P, Chan WM, Wu AK, Lung KC, Tsang OT, Leung WS, Hung IF, Yuen KY, Chen Z. Acute SARS-CoV-2 infection impairs dendritic cell and T cell responses. Immunity. 2020;53(4):864-77.e5. https://doi.org/10.1016/j. immuni.2020.07.026.

Zhou Y, Chi J, Lv W, Wang Y. Obesity and diabetes as high-risk factors for severe coronavirus disease 2019 (Covid-19). Diabetes Metab Res Rev. 2021;37(2): e3377. https://doi.org/10.1002/dmrr.3377.

\section{Publisher's Note}

Springer Nature remains neutral with regard to jurisdictional claims in published maps and institutional affiliations.

Ready to submit your research? Choose BMC and benefit from:

- fast, convenient online submission

- thorough peer review by experienced researchers in your field

- rapid publication on acceptance

- support for research data, including large and complex data types

- gold Open Access which fosters wider collaboration and increased citations

- maximum visibility for your research: over 100M website views per year

At BMC, research is always in progress.

Learn more biomedcentral.com/submissions 